\title{
Large-scale features of Pliocene climate: results from the Pliocene Model Intercomparison Project
}

\author{
A. M. Haywood ${ }^{1}$, D. J. Hill ${ }^{1,2}$, A. M. Dolan ${ }^{1}$, B. L. Otto-Bliesner ${ }^{3}$, F. Bragg ${ }^{4}$, W.-L. Chan $^{5}$, M. A. Chandler ${ }^{6}$, \\ C. Contoux ${ }^{7,8}$, H. J. Dowsett ${ }^{9}$, A. Jost ${ }^{8}$, Y. Kamae ${ }^{10}$, G. Lohmann ${ }^{11}$, D. J. Lunt ${ }^{4}$, A. Abe-Ouchi ${ }^{5,12}$, S. J. Pickering ${ }^{1}$, \\ G. Ramstein ${ }^{7}$, N. A. Rosenbloom ${ }^{3}$, U. Salzmann ${ }^{13}$, L. Sohl ${ }^{6}$, C. Stepanek ${ }^{11}$, H. Ueda ${ }^{10}$, Q. Yan ${ }^{14}$, and Z. Zhang ${ }^{14,15}$ \\ ${ }^{1}$ School of Earth and Environment, Earth and Environment Building, University of Leeds, Leeds, LS2 9JT, UK \\ ${ }^{2}$ British Geological Survey, Keyworth, Nottingham, UK \\ ${ }^{3}$ National Center for Atmospheric Research, Boulder, Colorado, USA \\ ${ }^{4}$ School of Geographical Sciences, University of Bristol, University Road, Bristol, BS8 1SS, UK \\ ${ }^{5}$ Atmosphere and Ocean Research Institute, University of Tokyo, Kashiwa, Japan \\ ${ }^{6}$ Columbia University - NASA/GISS, New York, NY, USA \\ ${ }^{7}$ Laboratoire des Sciences du Climat et de l'Environnement, Saclay, France \\ ${ }^{8}$ Unité Mixte de Recherche 7619 SISYPHE, Université Pierre-et-Marie Curie Paris VI, Paris, France \\ ${ }^{9}$ US Geological Survey, MS 926A, 12201 Sunrise Valley Dive, Reston, VA 20192, USA \\ ${ }^{10}$ Graduate School of Life and Environmental Sciences, University of Tsukuba, Tsukuba, Japan \\ ${ }^{11}$ Alfred Wegener Institute for Polar and Marine Research, Bremerhaven, Germany \\ ${ }^{12}$ Research Institute for Global Change, JAMSTEC, Yokohama, Japan \\ ${ }^{13}$ Faculty of Engineering and Environment, Northumbria University, Newcastle upon Tyne, NE1 8ST, UK \\ ${ }^{14}$ Institute of Atmospheric Physics, Chinese Academy of Sciences, Beijing, China \\ ${ }^{15}$ Bjerknes Centre for Climate Research, Bergen, Norway \\ Correspondence to: A. M. Haywood (earamh@leeds.ac.uk)
}

Received: 6 July 2012 - Published in Clim. Past Discuss.: 30 July 2012

Revised: 12 December 2012 - Accepted: 23 December 2012 - Published: 25 January 2013

\begin{abstract}
Climate and environments of the mid-Pliocene warm period ( 3.264 to $3.025 \mathrm{Ma}$ ) have been extensively studied. Whilst numerical models have shed light on the nature of climate at the time, uncertainties in their predictions have not been systematically examined. The Pliocene Model Intercomparison Project quantifies uncertainties in model outputs through a coordinated multi-model and multi-model/data intercomparison. Whilst commonalities in model outputs for the Pliocene are clearly evident, we show substantial variation in the sensitivity of models to the implementation of Pliocene boundary conditions. Models appear able to reproduce many regional changes in temperature reconstructed from geological proxies. However, data/model comparison highlights that models potentially underestimate polar amplification. To assert this conclusion with greater confidence, limitations in the time-averaged proxy data currently available must be addressed. Furthermore, sensitivity tests ex-
\end{abstract}

ploring the known unknowns in modelling Pliocene climate specifically relevant to the high latitudes are essential (e.g. palaeogeography, gateways, orbital forcing and trace gasses). Estimates of longer-term sensitivity to $\mathrm{CO}_{2}$ (also known as Earth System Sensitivity; ESS), support previous work suggesting that ESS is greater than Climate Sensitivity (CS), and suggest that the ratio of ESS to CS is between 1 and 2, with a "best" estimate of 1.5.

\section{Introduction}

\subsection{The mid-Pliocene warm period}

The mid-Pliocene warm period (mPWP) represents an interval of warm and stable climate between 3.264 and 3.025 Ma BP (Dowsett et al., 2010; Haywood et al., 2010). 
It sits within the Piacenzian Stage of the Late Pliocene according to the geological timescale of Gradstein et al. (2004). The recent redefinition of the base of the Pleistocene to include the Gelasian had led to this interval also being referred to as the mid-Piacenzian warm period (Dowsett et al., 2012), but we retain the use of mid-Pliocene warm period here for consistency with previous work.

Both geological data and climate model outputs have shed light on the nature of mid-Pliocene climate and environments. During warm phases of the mid-Pliocene, highlighted by negative excursions in $\delta^{18} \mathrm{O}$ from benthic foraminifera, Antarctic and/or Greenland ice volume may have been reduced (Lunt et al., 2008; Hill et al., 2010; Naish et al., 2009; Pollard and DeConto, 2009; Dolan et al., 2011), and between 2.7 and 3.2 Ma BP peak sea level is estimated to have been $22 \pm 10 \mathrm{~m}$ higher than modern (Dowsett and Cronin, 1990; Miller et al., 2012). Sea surface temperatures (SSTs) were warmer (Dowsett et al., 2010), particularly in the higher latitudes and upwelling zones (e.g. Dekens et al., 2007; Dowsett et al., 2012). Sea ice cover also declined substantially (e.g. Cronin et al., 1993; Polyak et al., 2010; Moran et al., 2006). On land, the global extent of arid deserts decreased, and forests replaced tundra in the Northern Hemisphere (e.g. Salzmann et al., 2008). The global annual mean temperature may have increased by more than $3{ }^{\circ} \mathrm{C}$ (e.g. Haywood and Valdes, 2004). Meridional and zonal temperature gradients were reduced, which had a significant impact on the Hadley and Walker circulations (e.g. Contoux et al., 2012; Haywood et al., 2000; Kamae et al., 2011). The East Asian Summer Monsoon, as well as other monsoon systems, may have been enhanced (e.g. Wan et al., 2010).

Given the abundance of proxy data, the mPWP has become a focus for data/model comparisons that attempt to analyse the ability of climate models to reproduce a warm climate state in earth history (e.g. Haywood and Valdes, 2004; Salzmann et al., 2008; Dowsett et al., 2011, 2012). Furthermore, the $\mathrm{mPWP}$ has been proposed as an important interval to assess the sensitivity of climate to near-current concentrations of carbon dioxide $\left(\mathrm{CO}_{2}\right)$ in the long term (hundreds to thousands of years; Lunt et al., 2010).

\subsection{Assessing uncertainty in models}

Whilst a considerable number of climate simulations are available for the mPWP, they have been conducted using only a few climate models. Although there appears to be agreement among the models over certain aspects of climate during the mPWP (e.g. Haywood et al., 2000, 2009), there are likely to be significant differences in the details of their simulations, particularly regionally (Haywood et al., 2009). Inconsistencies are to be expected due to structural differences in models, and from differences in experimental design. The exploration of uncertainty in model simulations of past climate has taken three primary forms. The first two include the use of a single model to either perform boundary condition sensitivity experiments (e.g. Haywood et al., 2007; Lunt et al., 2008; Robinson et al., 2011), or to perform a perturbed physics ensemble (e.g Plio-QUMP; e.g. Pope et al., 2011). The third method uses a standardised experimental design in an ensemble composed of different climate models (a multimodel ensemble; e.g. Braconnot et al., 2007).

The Paleoclimate Modelling Intercomparison Project (PMIP) was initiated in 1991 to co-ordinate the systematic study of climate models, and to assess their ability to simulate past climates (e.g. Joussaume and Taylor, 1995; Hoar et al., 2004; Zheng et al., 2008). PMIP also encourages the preparation of global reconstructions of palaeoclimates that can be used to evaluate climate models (e.g. Prentice and Webb, 1998). The focus of the studies carried out by PMIP has, until recently, been largely focussed on the Last Glacial Maximum and the mid-Holocene. However, in 2008 the Pliocene Modelling Intercomparison Project (PlioMIP) was added as a component of PMIP. Previously, there had only been limited efforts in documenting differences in model simulations of the mPWP. For example, Haywood et al. (2000) attempted a model intercomparison between versions of the Hadley Centre for Climate Prediction and Research, the Goddard Institute for Space Studies (GISS) and National Center for Atmospheric Research (NCAR) climate models. This comparison was hampered by the fact that the experimental design used within these studies varied.

Haywood et al. (2009) compared the outputs from two mPWP experiments using versions of the Hadley Centre and Goddard Institute for Space Studies atmosphere-only climate models (HadAM3 and GCMAM3) in a more systematic way. Whilst the models were consistent in the simulation of largescale differences in surface air temperature and total precipitation rates, significant variations were noted at regional scales (i.e. in the Arctic). Terrestrial data/model comparison indicated that HadAM3 provided a closer fit to proxy data (biome distributions) in the mid- to high latitudes. However, GCMAM3 performed better than HadAM3 in the tropics.

Whilst the scope of the model intercomparison presented in Haywood et al. (2009) was limited, it served to encourage the palaeoclimate modelling community to establish a larger model intercomparison project (PlioMIP). Here we present an initial model intercomparison focussed on the large-scale features of $\mathrm{MPWP}$ climate derived from the PlioMIP ensemble. PlioMIP established the design for two initial experiments. Experiment 1 used atmosphere-only climate models (AGCMs). Experiment 2 utilised coupled atmosphereocean climate models (AOGCMs) where SSTs and sea ice were predicted variables. We focus on the presentation of the global annual mean surface air temperature response in Experiment 1 and 2, zonal patterns of temperature and precipitation change, polar amplification, comparisons of model results to proxy data, and finally calculations of longer-term climate sensitivity as defined by Lunt et al. (2010; Earth System Sensitivity). 


\section{Boundary conditions and experimental design}

\subsection{Participating modelling groups}

Details of participating groups and models, and which experiment each group performed (Experiment 1 or 2 or both), can be found in Table 1. For Experiment 1 seven modelling groups completed and submitted data from their model integrations. For Experiment 2 eight modelling groups completed and submitted data. The models used in both Experiment 1 and 2 sample differing levels of complexity and resolution from higher-resolution IPCC AR5-class models, to intermediate resolution models. Details of boundary conditions and their implementation in each model, as well as the basic climatologies from the majority of the models used in this study, can be found in a PlioMIP special edition of the Journal Geoscientific Model Development (http: //www.geosci-model-dev.net/special_issue5.html).

\subsection{Boundary conditions}

Full details of the boundary conditions used for PlioMIP Experiments 1 and 2 are provided in Haywood et al. (2010) and Haywood et al. (2011), respectively. In brief both experiments utilised the US Geological Survey PRISM3D boundary condition data set (Dowsett et al., 2010). For Experiment 1 , this included information on monthly SSTs and sea ice distributions, vegetation cover, sea level, ice sheet extent and topography. For Experiment 2 modelling groups were given the choice of how to initialise their ocean model for the mPWP. They could spin up their model from a standard pre-industrial control run, or specify the PRISM3D data set of ocean temperatures (Dowsett et al., 2009). Given the challenging nature of changing the land/sea mask in some atmosphere-ocean climate models, two versions of Pliocene boundary conditions were provided for both Experiment 1 and 2. The preferred data set included a change in the land/sea mask accommodating the removal of the West Antarctic Ice Sheet (WAIS), an increase in sea level of 25 $\mathrm{m}$, and the infilling of the Hudson Bay. The alternate data set specified no changes in the land/sea mask but did remove the WAIS as far as possible by reducing topography down to sea level. The differences between the preferred and alternate boundary condition data sets are most striking over West Antarctica, which is fully deglaciated in the preferred data set, but set to near sea level and covered with tundra vegetation in the alternate boundary condition data set. The selection of preferred or alternate boundary conditions for each participating group is provided in Table 1. The impact on predictions of Pliocene climate from the selection of either preferred or alternate boundary condition protocols will be examined within single models set up with either boundary condition option in the near future.

NetCDF versions of all boundary conditions used for PlioMIP Experiment 1 and 2, along with guidance notes for boundary condition implementation can be found at http://geology.er.usgs.gov/eespteam/prism/prism_pliomip_ data.html. They have also been uploaded as a Supplement to Haywood et al. (2011).

\subsection{Experimental design}

The design of Experiment 1 and 2 is outlined in Haywood et al. (2010) and Haywood et al. (2011), respectively. In both experiments the atmospheric concentration of carbon dioxide $\left(\mathrm{CO}_{2}\right)$ was set at $405 \mathrm{ppmv}$. This value is towards the upper limit of the uncertainty range provided by recently published $\mathrm{CO}_{2}$ proxy records (e.g. Pagani et al., 2010; Seki et al., 2010; Bartoli et al., 2011). All other trace gasses were specified at a pre-industrial concentration and the selected orbital configuration was unchanged from modern. A $50 \mathrm{yr}$ integration length was specified as a minimum for Experiment 1 , with the final $30 \mathrm{yr}$ used to calculate the required climatological means. A minimum integration length of $500 \mathrm{yr}$ was specified for Experiment 2, which is long enough to allow at least the surface climatology and oceans to intermediate depth to reach an equilibrium condition. Again the final $30 \mathrm{yr}$ were used to calculate climatological means. Required fields and data formats that all groups were asked to provide can be found at http://geology.er.usgs.gov/eespteam/ prism/prism_pliomeet11.html.

\section{Results: PlioMIP Experiments 1 and 2}

\subsection{Global annual mean temperature change and hydrological response}

For the Experiment 1 ensemble, a range of global annual mean SAT anomalies from 1.97 to $2.80^{\circ} \mathrm{C}$ is simulated, while in Experiment 2, the ensemble range is between 1.84 and $3.60^{\circ} \mathrm{C}$ (Table 2). No direct relationship between the magnitude of Pliocene SAT anomaly and Climate Sensitivity (the stated equilibrium temperature response to a doubling of $\mathrm{CO}_{2}$ in the model) is seen (Table 2), demonstrating the importance of long-term climate drivers in mid-Pliocene warming. However, we note that MIROC4m and the COSMOS models have the two highest mid-Pliocene global annual SAT anomalies, as well as the highest published Climate Sensitivity estimates, implying $\mathrm{CO}_{2}$ and fast feedbacks to be among the primary drivers. SAT anomalies over land $\left(2.1\right.$ to $\left.5.1^{\circ} \mathrm{C}\right)$ are greater, and show a larger spread of response, than either SATs over the oceans or SSTs. This is to be expected given the additional complications of orography and vegetation and their influence on SAT over land. SATs over the oceans increase by 1.5 to $3.2^{\circ} \mathrm{C}$ and SSTs increase by 1.1 to $2.2^{\circ} \mathrm{C}$ (Fig. 1).

For Experiment 1 global annual mean precipitation rates increase by 0.04 to $0.11 \mathrm{~mm} \mathrm{day}^{-1}$ (Fig. 1). The changes in global precipitation in Experiment 1 are dominated by the increases over the land, whereas the specified increases in 


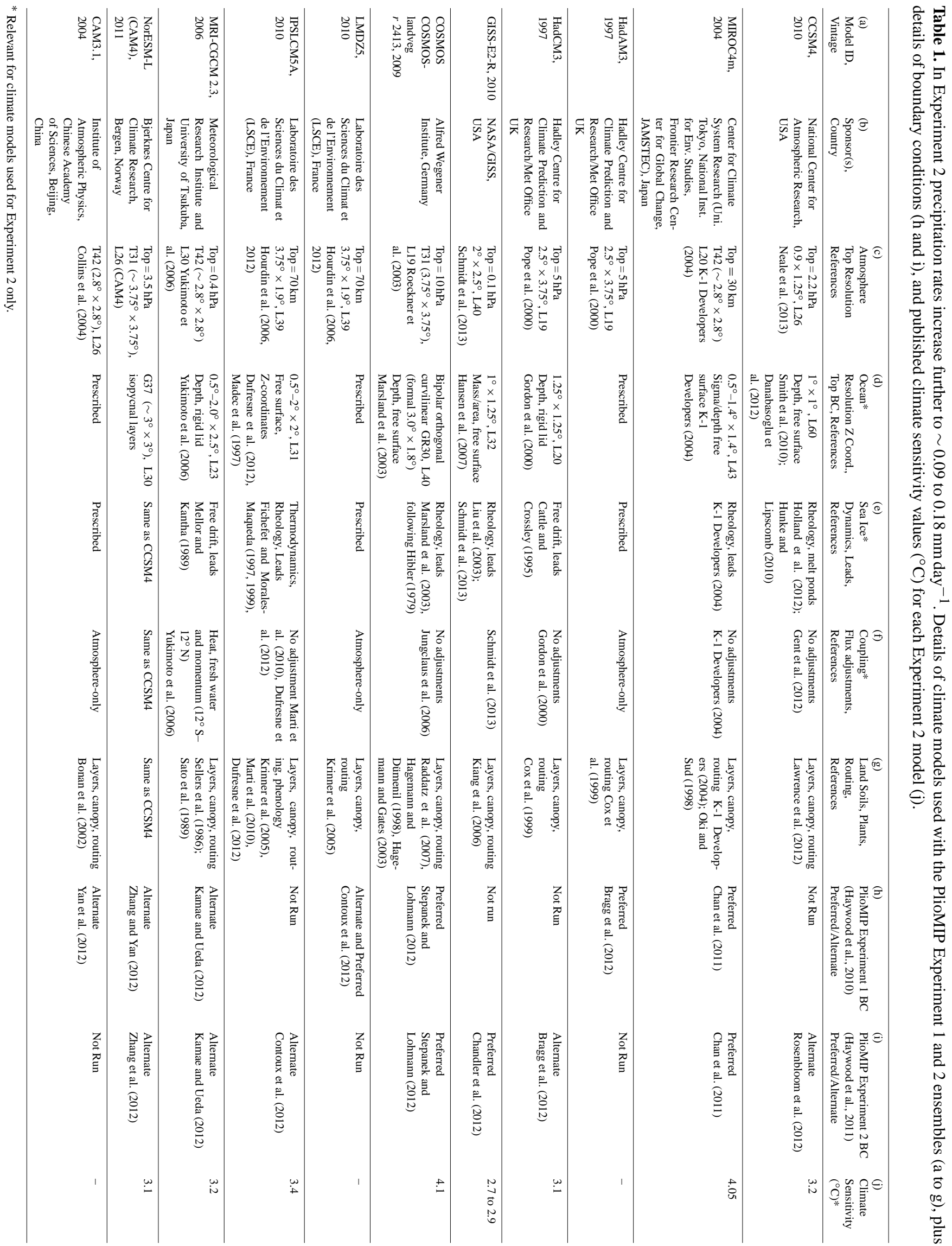




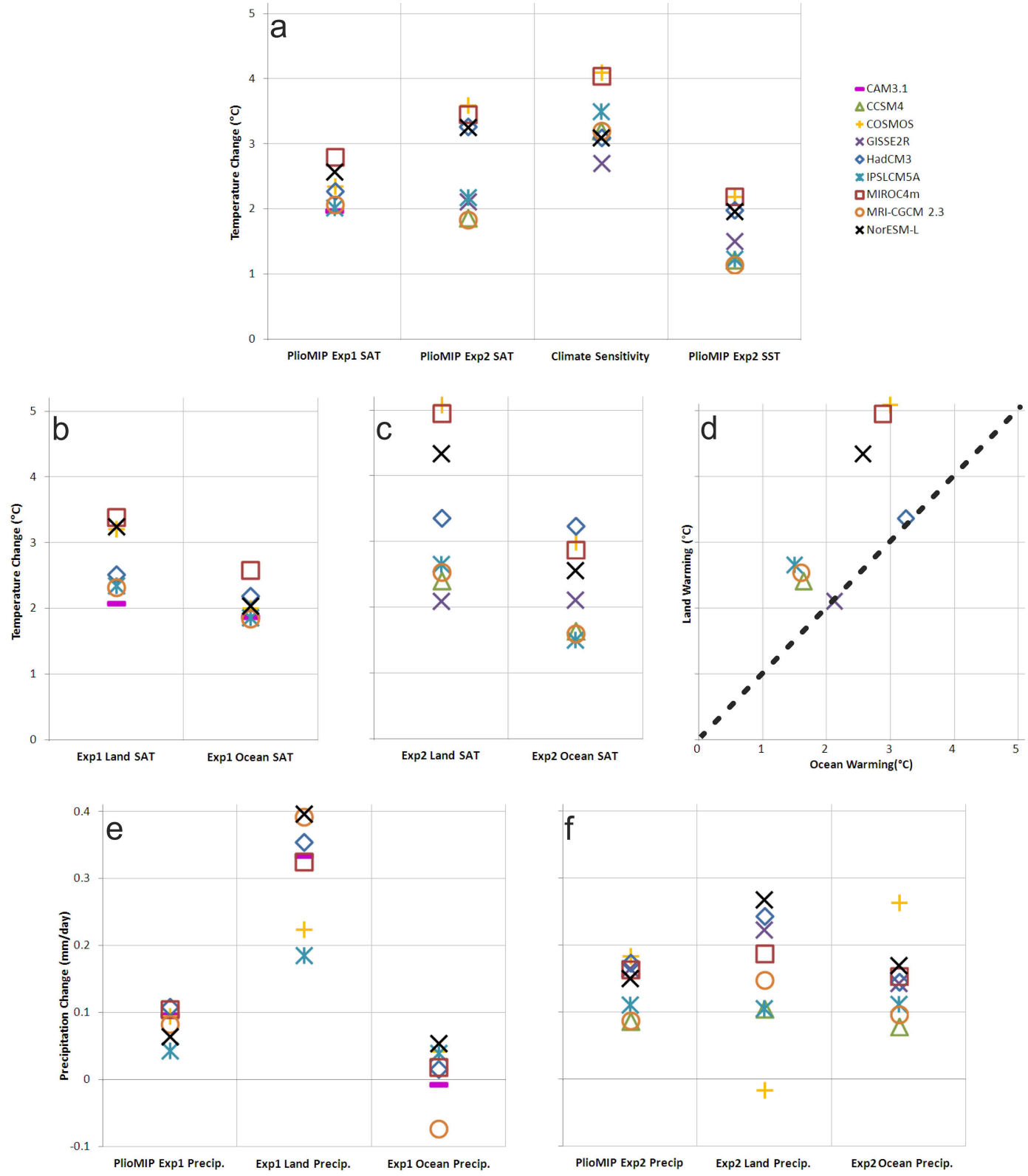

Fig. 1. (a) Global annual mean surface air temperature anomalies (mPWP minus pre-industrial control experiment) from each model in the PlioMIP Experiment 1 and 2 ensembles. Published estimates of Experiment 2 models' equilibrium climate sensitivity also provided, alongside the global mean SST anomalies for each model in Experiment 2. Annual mean surface air temperature anomalies from each Experiment 1 (b) and Experiment 2 (c) simulation separated into response over land and oceans. (d) SAT warming over land against ocean SAT warming for all Experiment 2 simulations. Global, land and ocean annual mean total precipitation rate anomalies for all simulations from Experiment 1 (e) and Experiment 2 (f).

SSTs are associated with very little increase in precipitation over the ocean. In Experiment 2 precipitation rates increase further to $\sim 0.09$ to $0.18 \mathrm{~mm} \mathrm{day}^{-1}$. MIROC4m, COSMOS and HadCM3 simulate the largest changes in total precipitation rate in the ensemble. A much smaller contrast is seen between increases on the land and over the ocean, although the partitioning of this increase is highly variable from model to model (Fig. 1).

\subsection{Multi-model mean surface air temperature and precipitation (Experiment 1)}

To facilitate the production of annual multi-model mean (MMM) SAT and precipitation rate anomalies (Experiment 1 and 2), as well as SST anomalies (for Experiment 2 only), each participating models' mPWP simulation was differenced to its respective pre-industrial control experiment. 
Table 2. (a) Experiment 2 models included in the assessment of Climate Sensitivity (CS) versus Earth System Sensitivity (ESS) plus the ensemble means; (b) calculated anomaly in global annual mean surface air temperatures $\left({ }^{\circ} \mathrm{C}\right)$; (c) published estimates of $\mathrm{CS}\left({ }^{\circ} \mathrm{C}\right)$; (d) calculated estimates of ESS $\left({ }^{\circ} \mathrm{C}\right)$; (e) ratio of ESS to CS; (f) energy balance at the Top of the Atmosphere in $\mathrm{W} \mathrm{m}^{-2}$ for the control and Pliocene experiments.

\begin{tabular}{lrrrrl}
\hline (a) & (b) & $\begin{array}{r}\text { (c) } \\
\text { Experiment } 2\end{array}$ & $\begin{array}{r}\text { ESS }\left({ }^{\circ} \mathrm{C}\right) \\
=\text { mPWP }\end{array}$ & $\begin{array}{l}\text { (e) } \\
\text { Climate }\end{array}$ & $\begin{array}{l}\text { TOA Energy } \\
\text { Balance }\left(\mathrm{W} \mathrm{m}^{-2}\right)\end{array}$ \\
Models/Mean & $\Delta T\left({ }^{\circ} \mathrm{C}\right)$ & $\begin{array}{r}\mathrm{CS} \\
\left({ }^{\circ} \mathrm{C}\right)\end{array}$ & $\Delta T \cdot 1.88$ & ESS/CS & CTRL:Pliocene \\
\hline CCSM4 & 1.86 & 3.2 & 3.51 & 1.1 & $-0.1: 0.1$ \\
COSMOS & 3.60 & 4.1 & 6.77 & 1.7 & $2.4: 2.3$ \\
GISS-E2-R & 2.12 & 2.7 & 3.98 & 1.5 & $0.45: 0.15$ \\
HADCM3 & 3.27 & 3.1 & 6.16 & 2.0 & $-0.79: 0.16$ \\
IPSLCM5A & 2.18 & 3.4 & 4.10 & 1.2 & $0.21: 0.81$ \\
MIROC4m & 3.46 & 4.05 & 6.51 & 1.6 & $0.81: 0.90$ \\
MRI-CGCM 2.3 & 1.84 & 3.2 & 3.45 & 1.1 & $2.9: 3.0$ \\
NorESM-L & 3.27 & 3.1 & 6.14 & 2.0 & $2.1: 2.1$ \\
\hline Ensemble Mean & 2.66 & 3.36 & 5.01 & 1.5 & - \\
\hline
\end{tabular}

These data were then re-gridded on to the regular $2^{\circ} \times 2^{\circ}$ latitude/longitude grid of the PRISM3D boundary conditions. MMM fields were then calculated as a simple mean of each of the individual model experiments. This allows us to evaluate the ensemble as a whole, without down-weighting any of the individual models. Future work may include evaluation of each individual model against mPWP data and the production of weighted MMM to make a combined model and data estimate of mPWP climate. Individual model anomalies for SAT and total precipitation rate on their common/local grids are included in Figs. S1 and S2 in the Supplement.

The MMM SAT anomaly (Fig. 2) from pre-industrial shows minimal change between $15^{\circ}$ north and south of the Equator, with the exception of the eastern equatorial Pacific, which displays a warming of up to $3{ }^{\circ} \mathrm{C}$. Between $15^{\circ}$ and $90^{\circ}$ north and south of the Equator the SAT anomaly becomes progressively stronger, particularly over Greenland and the Arctic Basin, and in areas of West and East Antarctica. The zonal MMM SAT anomaly shows little or no change in the tropics and a clear polar amplification of temperatures. Temperatures increase by $>10^{\circ} \mathrm{C}$ in the Arctic and up to $20^{\circ} \mathrm{C}$ in the Antarctic (Fig. 2).

Uncertainties within the MMM reconstruction can be evaluated in terms of the spread of the predictions within the ensemble, with two standard deviations $(2 \sigma)$ being a standard measure (Le Treut et al., 2007). However, this ensemble is only small, so our use of this measure does not imply it is normally distributed, nor is it necessarily a $95 \%$ confidence interval. Over the open oceans the models' SATs do not vary significantly from one another due to SSTs being prescribed. A $2 \sigma$ of 1 to $4{ }^{\circ} \mathrm{C}$ is common in the MMM over land (Fig. 2). In regions dominated by ice sheets or sea ice, the $2 \sigma$ increases to 6 to $8^{\circ} \mathrm{C}$. In the same regions where the land/sea mask was altered (i.e. West Antarctica, the margins of East Antarctica and the Hudson Bay), the $2 \sigma$ exceeds $8^{\circ} \mathrm{C}$; such high inter-model differences are attributable to the application of either the PlioMIP preferred or alternate experimental design (Haywood et al., 2010, 2011).

For total precipitation rate, the MMM indicates a complex response in the tropics (Fig. 2). In the central and western Pacific precipitation rates near the Equator are reduced by $\sim 1 \mathrm{~mm}$ day $^{-1}$. At $15^{\circ}$ north and south of the Equator, and in the eastern equatorial Pacific, precipitation rates increase by more than $2 \mathrm{~mm}_{\text {day }}{ }^{-1}$. Over the African continent and the Indian sub-continent precipitation rates generally increase $\left(0.1\right.$ to $\left.\sim 2 \mathrm{~mm} \mathrm{day}^{-1}\right)$. Over the majority of the Indian Ocean precipitation rates are reduced. Over North America precipitation rates increase in the northwest and are reduced in the southwest. Over ice-free regions of Greenland and Antarctica precipitation rates increase. Finally, large increases in precipitation rate $\left(>2 \mathrm{~mm} \mathrm{day}^{-1}\right)$ are predicted in the northern North Atlantic and the Nordic Seas.

Such regional differences are reproduced in the zonal MMM mean precipitation anomaly (Fig. 2). Around the Equator precipitation rates decrease by $\sim 0.4 \mathrm{~mm} \mathrm{day}^{-1} .15^{\circ}$ north and south of the Equator precipitation rates increase by up to $0.3 \mathrm{~mm} \mathrm{day}^{-1}$. The zonal MMM indicates increased precipitation rates in the Southern Hemisphere westerlies. In general precipitation rates increase in the Northern Hemisphere north of $30^{\circ} \mathrm{N}$ and peak changes are seen at $\sim 80^{\circ} \mathrm{N}$. In the tropics the $2 \sigma$ within the Experiment 1 ensemble can exceed $3 \mathrm{~mm} \mathrm{day}^{-1}$, whereas in most other areas the $2 \sigma$ is no greater than $1.5 \mathrm{~mm} \mathrm{day}^{-1}$ (Fig. 2).

\subsection{Multi-model mean surface air/sea surface temperature/precipitation (Experiment 2)}

The process for constructing annual MMMs for Experiment 2 was the same as that adopted for Experiment 1, except for the inclusion of SSTs. Individual model anomalies for SAT, total precipitation rate and SSTs on their common/local grids are included in Figs. S3, S4 and S5 in the Supplement. The LSCE and GISS modelling groups have recently provided additional simulations for Experiment 2 to those used for the calculation of the MMMs. The degree to which these additional data alter the calculated MMM for Experiment 2 is shown in Fig. S7 in the Supplement. In the tropics the MMM indicates a general pattern of SAT warming of 1 to $2{ }^{\circ} \mathrm{C}$ over the oceans (Fig. 3). In the same region warming over the land ranges from 1 to $6^{\circ} \mathrm{C}$. From the mid to high latitudes a pattern of progressively larger SAT anomalies is predicted reaching a maximum change over Greenland and the Arctic, West Antarctica and areas of East Antarctica. The zonal mean SAT anomaly displays $\sim 2{ }^{\circ} \mathrm{C}$ warming in the tropics, increasing to $\sim 6^{\circ} \mathrm{C}$ and $9{ }^{\circ} \mathrm{C}$ in the high latitudes of the Northern and Southern Hemispheres, respectively (Fig. 3). The $2 \sigma$ around the zonal MMM SAT anomaly is broad in the high latitudes of both hemispheres. Models largely agree in their predictions of tropical SAT change over the oceans and land (with greater variation), whilst in the North Atlantic 

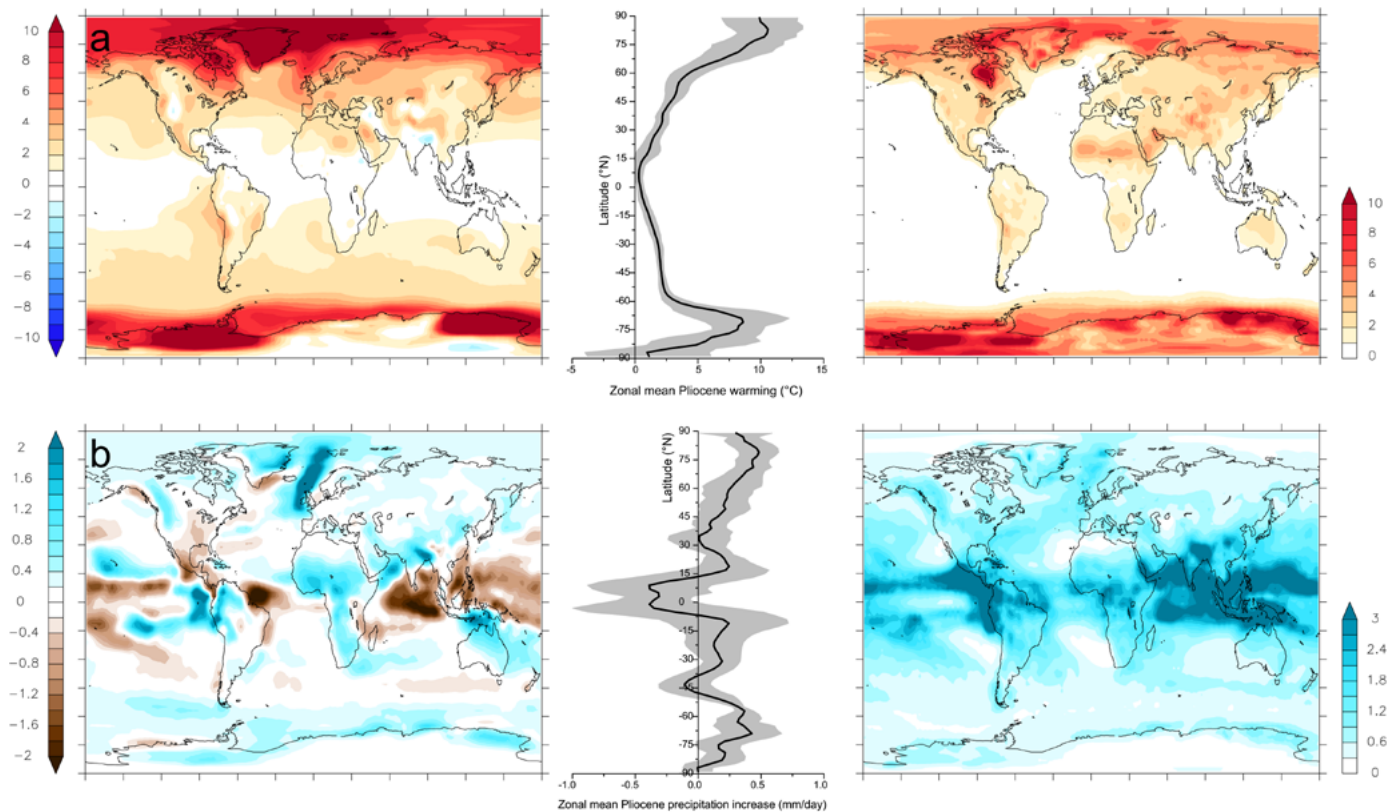

Fig. 2. Multi-model means, zonal means and model $2 \sigma$ from the Experiment 1 ensemble. (a) Mean annual surface air temperature anomaly (Experiment 1 Pliocene minus pre-industrial control) and (b) mean annual total precipitation rate anomaly (Experiment 1 Pliocene minus pre-industrial control). Shading around the zonal mean is the model $2 \sigma$.

and the higher latitudes in general the $2 \sigma$ ranges from 2 to $10^{\circ} \mathrm{C}$ (Fig. 3).

The MMM indicates a large increase in total precipitation rates between the Equator and $15^{\circ} \mathrm{N}$, which can exceed $1 \mathrm{~mm} \mathrm{day}^{-1}$ (Fig. 3). In the Atlantic and Pacific Ocean basins, a reduction in precipitation rate is seen between the Equator and $15^{\circ} \mathrm{S}-30^{\circ} \mathrm{S}\left(0.1\right.$ to $\left.1 \mathrm{~mm} \mathrm{day}^{-1}\right)$. Regions influenced by the Indian and West African monsoons show a pattern of increased precipitation rates, and this is also seen in regions dominated by the mid-latitude storm tracks. The pattern of precipitation anomalies between the sub-tropics and mid-latitudes in the Northern Hemisphere (decline in the sub tropics and increases in the mid latitudes) is suggestive of a northward shift of the zone influenced by mid-latitude storms. Increased precipitation rates are predicted in ice-free regions of Greenland, West and East Antarctica. In the zonal MMM the pattern of enhanced precipitation rates from the Equator to $15^{\circ} \mathrm{N}$ is replicated, as is the general trend for precipitation rates to decrease from 15 to $30^{\circ}$ south. Precipitation rates in the mid-latitudes and to approximately $75^{\circ}$ north and south of the Equator are also enhanced by a maximum of $0.3 \mathrm{~mm} \mathrm{day}^{-1}$. The $2 \sigma$ of model results which contribute to the MMM is large $\left(0.1\right.$ to $\left.>3 \mathrm{~mm} \mathrm{day}^{-1}\right)$ in the tropics with greater consistency between models in the extra tropics (Fig. 3).

The MMM SST anomaly shows a pattern of increased global SSTs $\left(1\right.$ to $\left.5^{\circ} \mathrm{C}\right)$. Warmer mPWP SSTs are most pronounced in the North Pacific, Southern Ocean and in parts of the North Atlantic. The zonal MMM for SSTs, along with the calculated $2 \sigma$, confirms these basic trends, whilst highlighting regions of greater or lesser consistency between the model results. In the North Pacific the SST anomaly is large (up to $5^{\circ} \mathrm{C}$ ) and the standard deviation is generally no greater than $2{ }^{\circ} \mathrm{C}$ (Fig. 3). In contrast the SST response in the North Atlantic is weaker $\left(2\right.$ to $\left.3{ }^{\circ} \mathrm{C}\right)$, and at the same time the $2 \sigma$ from the ensemble is large (locally exceeding $4^{\circ} \mathrm{C}$ ). One model in the ensemble produces a different sign of change in this region in response to the implementation of Pliocene boundary conditions compared with other models (GISS-E2R; see Fig. S5c in the Supplement). The reasons for this are discussed in Chandler et al. (2012) and the associated interactive discussion of that paper. An additional Experiment 2 simulation from the GISS modelling group, utilising a different version of the GISS model with an improved representation of ocean mixing, provides a SST anomaly in the North Atlantic in broad agreement with the general response seen from all of the other models used within the Experiment 2 ensemble. The degree to which this additional simulation differs from the original GISS simulation and how it alters the calculated MMM for SST in the North Atlantic is shown in Figs. S6 and S7 in the Supplement.

\subsection{Multi-model means (Experiment 2 minus Experiment 1)}

For annual MMM SAT anomalies, differences between Experiments 1 and 2 exceeding 1 or $2^{\circ} \mathrm{C}$ are largely restricted to the North Atlantic and the Arctic (Fig. 4). The Nordic Seas and the Arctic east of Greenland exhibit differences 

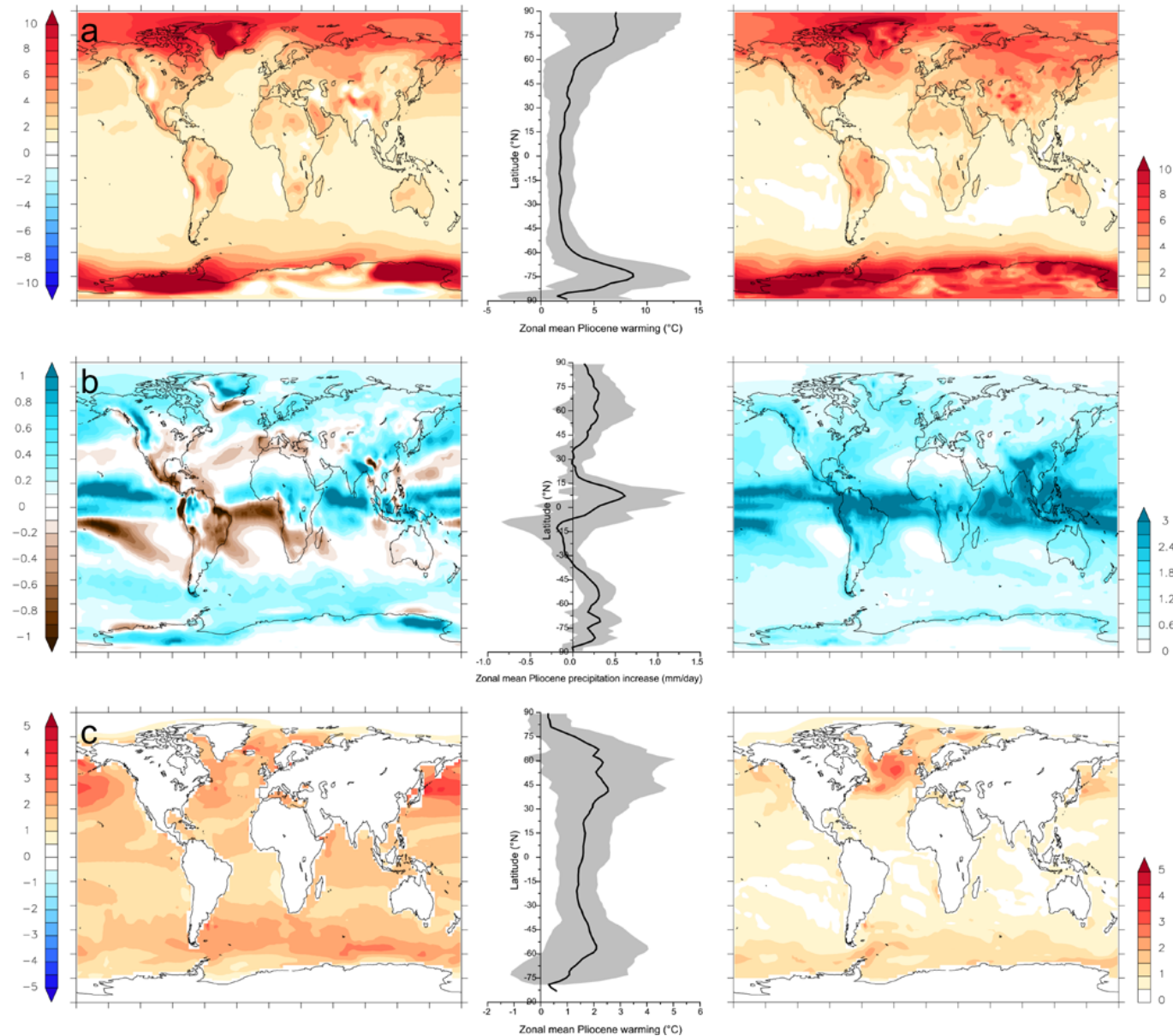

Fig. 3. Multi-model means, zonal means and model $2 \sigma$ from the Experiment 2 ensemble. (a) mean annual surface air temperature anomaly (Experiment 2 Pliocene minus pre-industrial control), (b) mean annual total precipitation rate anomaly (Experiment 2 Pliocene minus preindustrial control) and (c) mean annual sea surface temperature anomaly (Experiment 2 Pliocene minus pre-industrial control). Shading around the zonal mean is the model $2 \sigma$.

exceeding 6 to $8^{\circ} \mathrm{C}$ due to a weaker SAT anomaly predicted in Experiment 2. In the Antarctic sea ice region the Experiment $2 \mathrm{MMM}$ anomaly is also smaller than Experiment 1 $\left(\sim 1\right.$ to $\left.3{ }^{\circ} \mathrm{C}\right)$. In the tropics Experiment 2 generally displays a larger mean annual SAT anomaly than Experiment 1 by $\sim 1$ to $2{ }^{\circ} \mathrm{C}$. These trends are also reflected in the zonal MMM SAT difference between Experiment 2 and 1 anomaly. From the calculated differences in model $2 \sigma$ it is clear that the consistency of the MMM in high latitudes is substantially less in Experiment 2 than Experiment 1. This result is also repeated in the Southern Hemisphere sea ice region. In the tropics the calculated $2 \sigma$ on the MMM anomaly is far smaller than at the high latitudes $\left(\sim 4^{\circ}\right.$ rather than $\left.20^{\circ} \mathrm{C}\right)$, highlighting a greater consistency seen in the results from Experiment 1 and 2 (Fig. 4).

Differences between the MMM and zonal MMM's for Experiment 2 and 1 for total precipitation rate anomalies are particularly striking in the tropics (Fig. 4). In this region Experiment 2 predicts a larger anomaly in precipitation rates (wetter) over the oceans than Experiment 1. Conversely, the
Experiment 1 anomaly is greater in the tropics over land (drier) than Experiment 2 (Fig. 4). The calculated $2 \sigma$ on the Experiment 2 and 1 MMM total precipitation rate anomalies shows, as expected, an inverse pattern to that displayed for SAT. Model-predicted anomalies appear largely consistent to within $2 \mathrm{~mm} \mathrm{day}^{-1}$ in high and mid-latitudes, but are less consistent in the tropics (Fig. 4).

\subsection{Temperature and precipitation anomalies in response to $\mathrm{MPWP}$ boundary conditions}

For Experiment 1, and to a lesser degree Experiment 2, the MMM differences in mPWP climate are closely linked to the specified boundary conditions provided by the PRISM3D data set. Altered SST patterns, sea and land ice volumes are a first order control on the simulated variations of the mPWP climate relative to the pre-industrial. The variations in climate are driven by changes in sensible and latent heat fluxes (SST-driven), and variations in ocean/atmosphere heat exchange caused by differences in sea ice. 

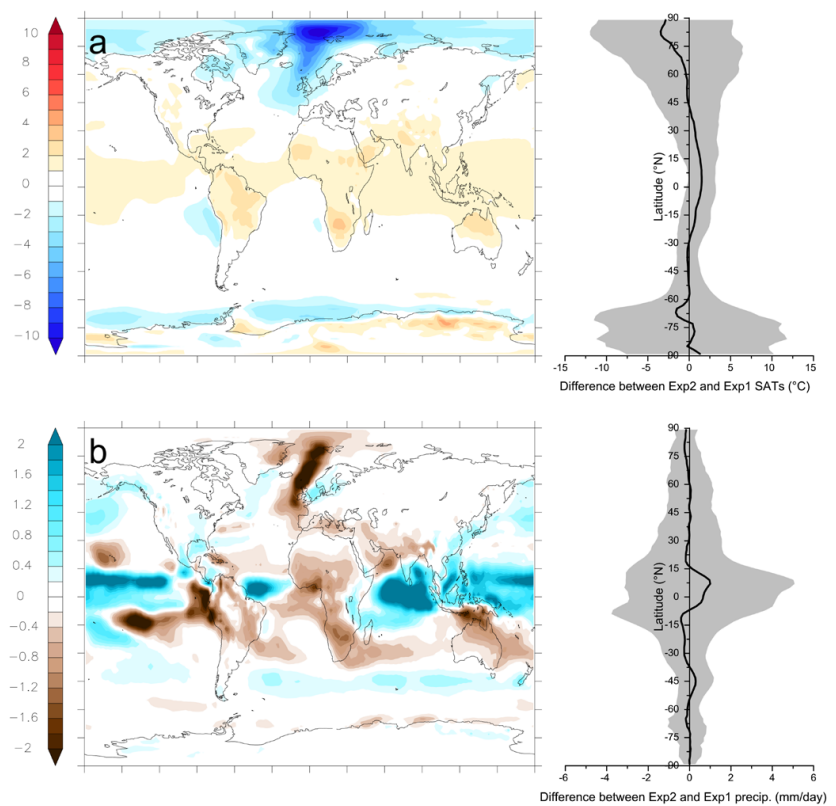

Fig. 4. Difference in multi-model mean anomalies between Experiment 2 and 1. (a) difference in mean annual SAT and zonal mean annual SAT anomalies. (b) difference in mean annual and zonal mean annual total precipitation rate anomalies. Shading around the mean represents the model $2 \sigma$.

\subsubsection{Experiment 1}

For Experiment 1 the MMM response in annual mean SAT and total precipitation rates are strongly controlled by the imposed boundary conditions from the PRISM3D data set. At high latitudes, reductions in specified land and sea ice generate a significant polar amplification of the SAT anomaly (Fig. 2), driven by local altitude changes and also ice/albedo feedbacks. This is augmented on land by a change in vegetation distribution from tundra to forest type biomes, changing surface albedo and evapo-transpiration rates. In the midlatitudes, SAT anomalies are strongly controlled by local vegetation changes and also by elevated SSTs (Fig. 2). Increasing total precipitation rates outside the tropics are correlated with SSTs, land and sea ice changes, and where vegetation patterns differ most from modern. The response of precipitation in the tropics appears to be driven by reduced meridional SST gradients generally, as well as reduced zonal SST gradients in the tropical Pacific and Atlantic Oceans (Fig. 2). SST gradient changes have a significant effect on the strength of Hadley and Walker circulations, and potentially also generate a general broadening of the Hadley Cell, explaining the redistribution of precipitation (Kamae et al., 2011). Over North America the precipitation rate anomaly displays a dipole pattern (wetter in the northwest and drier in the southeast of the continent). This appears to be an atmospheric teleconnection to the reduced zonal SST gradient in the tropical Pacific (Fig. 2; warmer eastern equatorial Pacific
SSTs). These conclusions based on the MMM are consistent with published analyses of the individual model results (e.g. Chan et al., 2011; Contoux et al., 2012; Kamae and Ueda, 2012; Zhang and Yan, 2012; Koenig et al., 2012).

\subsubsection{Experiment 2 minus Experiment 1}

Experiment 2 displays a number of the general trends and drivers for predicted climate differences described already for Experiment 1, with a number of important exceptions. The primary difference between the MMMs for Experiment 1 and 2 is dominated by Experiment 2 displaying a weaker high latitude SAT anomaly and warmer tropical temperatures (Fig. 4). This generates a steeper meridional temperature gradient. Zonal SAT gradients are also larger in Experiment 2 compared to Experiment 1 in the tropical Pacific (Fig. 4). These combined differences impact on the simulated precipitation rate response in the tropics in Experiment 2 through influencing the vigour of the Hadley and Walker circulations.

\section{Surface air/sea surface temperature comparisons}

\subsection{Point-based comparison of SATs and SSTs}

Figure 5 shows a traditional comparison of point-based proxy temperature anomalies to the MMM anomalies derived from Experiment 2. This analysis assesses the degree of agreement between the temperature anomalies of proxies and models, rather than comparing absolute temperature estimates. On land terrestrial temperature estimates are derived from Salzmann et al. $(2008,2013)$. In the Southern Hemisphere and tropics MMM SAT anomalies are within $3{ }^{\circ} \mathrm{C}$ of proxy anomalies. In the Northern Hemisphere, particularly beyond $40^{\circ} \mathrm{N}$, the MMM underestimates the magnitude of SAT warming by as much as $15^{\circ} \mathrm{C}$. For the oceans SST anomalies are derived from Dowsett et al. (2010) and Dowsett et al. (2012). The analysis shown in Fig. 5 demonstrates a broad concordance between data and models apart from in the northern North Atlantic and Nordic Seas. Here the MMM underestimates the magnitude of change by as much as 8 to $10^{\circ} \mathrm{C}$. Whilst the difference between MMM SAT/SST and proxy-based SST anomalies is substantial in specific regions it is worth noting that $2 \sigma$ around the MMM can also be substantial reflecting the degree of model variation within the PlioMIP ensemble.

\subsection{Regional-scale comparison of SSTs and SATs}

Due to the different spatial scales considered by proxy-data and model outputs it is not surprising to see the kind of discord between proxies and model results seen in Fig. 5. To test the validity of the comparison previously shown, proxy and model simulations at a regional scale are analysed (Fig. 6). The globe is subdivided into the seven continents in the 


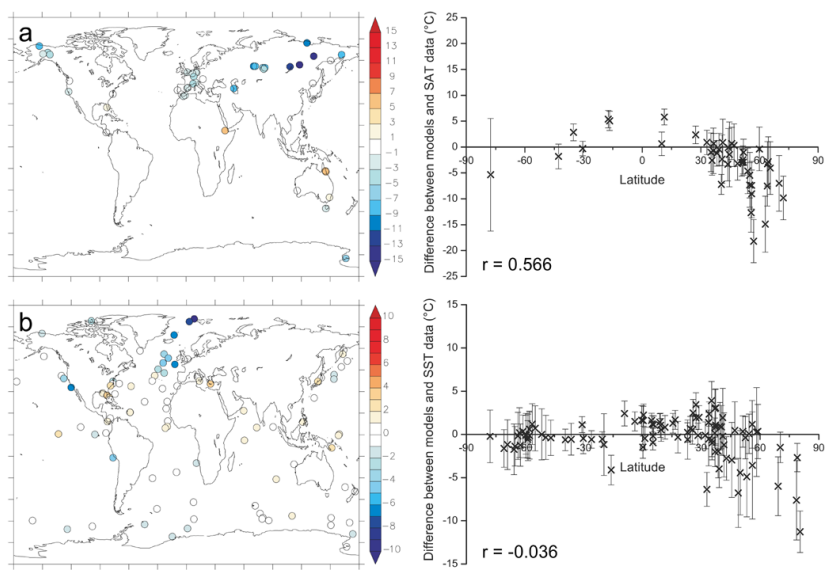

Fig. 5. Point-based data/model comparison of (a) surface air temperature and (b) sea surface temperature anomalies (modelled warming minus proxy data Pliocene warming) for Experiment 2. Error bars on the scatter plots refer to the $2 \sigma$ range derived from the Experiment 2 ensemble, while $r$ is the Pearson correlation coefficient between the modelled Pliocene warming anomaly and the data derived warming estimates.

terrestrial realm and the seven major ocean basins in the marine regime. Proxy temperature anomalies pertaining to each marine or terrestrial region were collated and averaged. For marine regions faunal analysis SST calculation methods provide information on cold and warm month SSTs (Dowsett et al., 2010, 2012). Available $\mathrm{Mg} / \mathrm{Ca}$ and alkenone palaeothermometry based estimates available for a sub-section of marine sites provide additional information on mean annual SSTs (Dowsett et al., 2010, 2012). These estimates are compared to regional mean annual and monthly changes in temperature computed from the Experiment 2 (marine and terrestrial regions) and Experiment 1 (terrestrial regions only) multi-model means. The calculated $2 \sigma$ values for SAT and SST derived from all the ensemble members are also included (Fig. 6).

In this analysis the general agreement between model outputs and SST proxy estimates for the Southern Ocean, North and South Pacific, Indian and South Atlantic Oceans highlighted in Fig. 5 is reiterated. In the Arctic Ocean, the model/data discord persists but is only marked when the model results are compared to geochemically based proxy mean annual SST estimates, rather than faunal analysisbased estimates for cold and warm month means. Any data/model discord in this region should be viewed with caution until multi-proxy temperature estimates are available from more marine localities in the Arctic.

For the North Atlantic, the regional comparison indicates more concordance between the models and proxy data than in the point-based analysis shown in Fig. 5, where the North Atlantic was shown as a clear region of major data/model discord. We interpret this difference as an indication of the models' ability to simulate the average amount of warming in the North Atlantic as a whole, whilst not necessarily reproducing the exact distribution of the SST increases vis-a-vis the PRISM3D localities used for SST reconstruction. Given the complex oceanography and steep SST gradients that exist in the North Atlantic (e.g. Kelly et al., 2010) this outcome is not surprising given the resolution of the ocean models used in this study.

In terms of data/model concordance over land there is agreement in most regions except for Asia where the Experiment 2 and 1 MMMs both underestimate the degree of MAT increase compared to the proxy data. Differences over Australia are at the limits of detection, while the single point over Antarctica is not representative of continental scale warming and suffers from uncertain chronology (Hill et al., 2007). Over Asia the analyses shown in Figs. 5 and 6 highlight the greater degree of warming reconstructed in the continental interior and high latitudes in the proxies compared to the MMMs. The results presented in this section have demonstrated interesting regional features of data/model concordance/discordance. However, they should be viewed as a preliminary analysis. More detailed data/model comparison for the PlioMIP Experiment 2 ensemble will be subject of additional studies in the near future.

\section{Calculation of Earth System Sensitivity}

\subsection{What is Earth System Sensitivity?}

Climate sensitivity (the temperature response of the earth to elevated $\mathrm{CO}_{2}$ concentrations) is a concept which has received much attention, as it is a simple and easily understood metric which gives a first-order indication of the magnitude of possible future climate change given increased $\mathrm{CO}_{2}$ emissions (e.g. Charney, 1979; Hansen et al., 2008; Meinshausen et al., 2009).

Estimates of climate sensitivity, which are based on models, are normally defined as the modelled global mean near surface air temperature equilibrium response to a sustained doubling of atmospheric $\mathrm{CO}_{2}$ concentration. In general, model-based estimates of climate sensitivity are most relevant for short timescales $(<100 \mathrm{yr})$, as typical climate models do not include feedbacks which act on longer timescales, and/or are not often run out to full equilibrium (Lunt et al., 2010; Hansen et al., 2008). Furthermore, no model includes all possible feedbacks even on short timescales. For example, feedbacks associated with atmospheric chemistry, non- $\mathrm{CO}_{2}$ greenhouse gases, and aerosols are only just being included in state-of-the-art models.

Earth System Sensitivity (ESS) has been defined by Lunt et al. (2010) as the equilibrium global mean near-surface $(\sim 2 \mathrm{~m})$ air temperature response to a sustained doubling of atmospheric $\mathrm{CO}_{2}$ concentrations, including all feedbacks and processes apart from those associated with the carbon cycle itself. By taking account of long timescale feedbacks, models 
Experiment 1
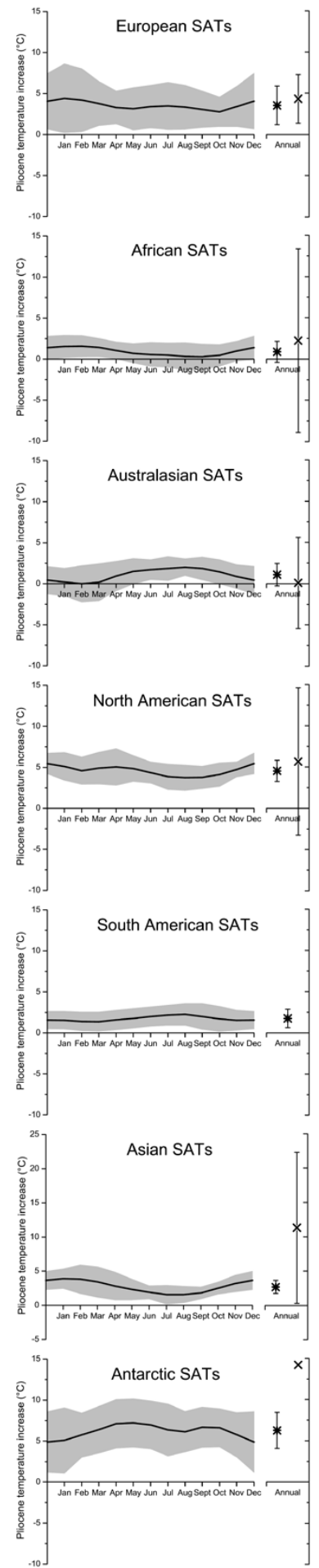
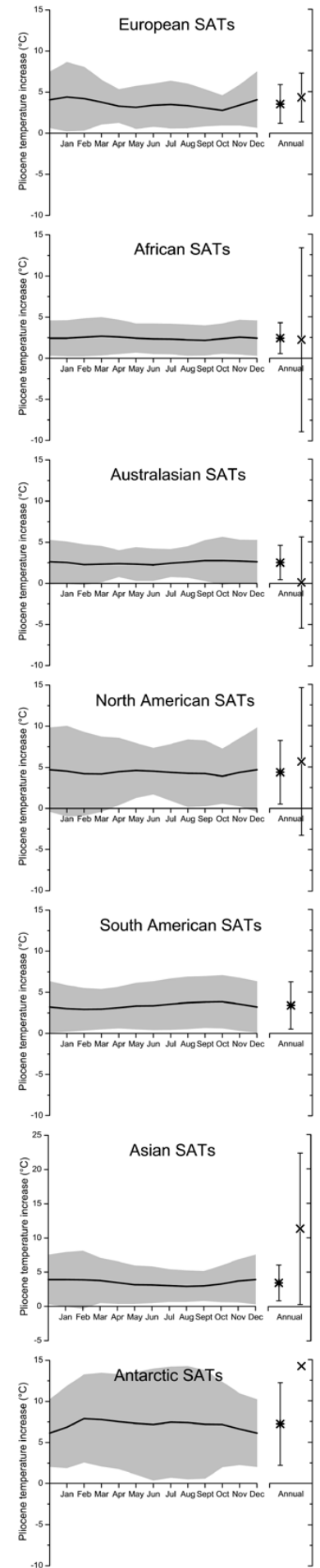
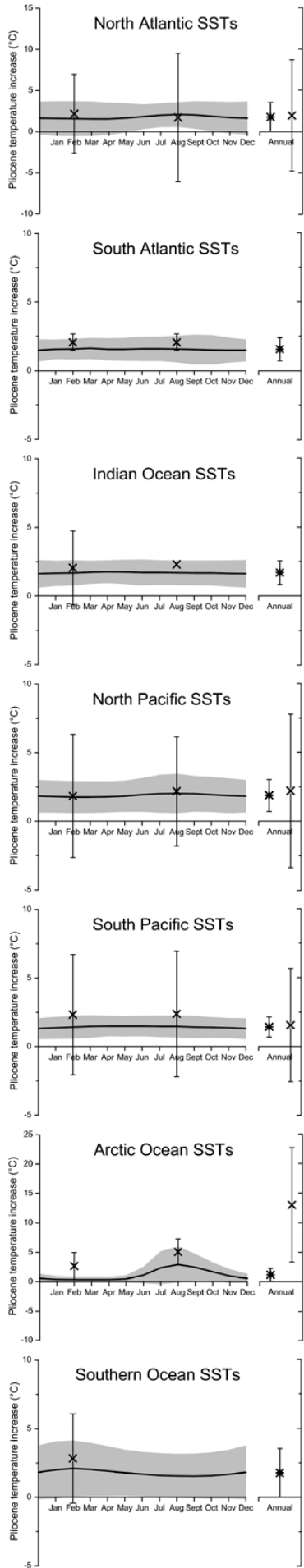

Fig. 6. Regional marine and terrestrial annual and monthly mean data/model comparisons. Comparison includes the calculated model $2 \sigma$ derived from Experiment 1 and 2 models regional averages. Left column: Experiment 1 terrestrial regions. Middle column: Experiment 2 terrestrial regions. Right column: Experiment 2 marine realm. Error bars on the data (crosses) are derived from spatial variability over the region (i.e. does not represent variability or uncertainty). In the annual means the stars represent the modelled annual mean and the crosses the proxy data. Terrestrial data comes from palynological and biome estimates (Salzmann et al., 2013). February and August SST estimates are derived from assemblage data, while annual mean SST data are Mg/Ca and alkenones estimates (Dowsett et al., 2010, 2012). 
can be used to estimate ESS. Palaeo data are very useful tools in determining ESS, as they provide the potential for providing the model with information on the long-term feedbacks, which are often problematic to model explicitly.

\subsection{Previous estimates of ESS using the MPWP}

The mPWP is useful for investigating the concept of ESS because it represents a world in quasi-equilibrium with high $\mathrm{CO}_{2}$ for a sufficient period that long-term feedbacks are close to equilibrium. Using a combined model-data approach, Lunt et al. (2010) estimated ESS to be between $30 \%$ and $50 \%$ greater than CS. They took a climate model (HadCM3), and imposed changes to the $\mathrm{CO}_{2}$, orography, ice sheet and vegetation model boundary conditions, which were consistent with changes observed in the MPWP palaeo record. They then evaluated the model simulation relative to MPWP SST records. Finally, they used a series of sensitivity studies to eliminate the orographic forcing effect, arguing that the remaining temperature signal was an approximation to ESS.

\subsection{Using PlioMIP Experiment 2 to inform estimates of ESS}

Here, we use the PlioMIP simulations from Experiment 2 to estimate ESS, using a similar approach to Lunt et al. (2010). Since the PRISM3D orography in the PlioMIP experimental design is similar to modern (Sohl et al., 2009), our approach is actually significantly simpler than Lunt et al. (2010) because we argue that in this case, the orographic effect is negligible. In the PRISM2 data set, which was used to provide the boundary conditions for the Lunt et al. (2010) estimates, mPWP and modern orographies were less similar. As such, we consider the elevated $\mathrm{CO}_{2}$ to be the ultimate forcing of the simulated mPWP warmth, and thus our simulations represent the equilibrium state of a world at 405 ppmv of $\mathrm{CO}_{2}$. To convert this to the usual definition of ESS (i.e. a $\mathrm{CO}_{2}$ doubling from 280 to $560 \mathrm{ppmv}$ ), the Pliocene warming is multiplied by $\ln (560.0 / 280.0) / \ln (405.0 / 280.0)=1.88$.

The global mean values are given in Table 2 for each model and the ensemble mean, along with the CS value from each model, and the ratio ESS/CS. There is a large spread in the ratio ESS/CS from 1.1 (CCSM4 and MRI-CGCM 2.3) to 2.0 (HadCM3 and NorESM-L). The ratio for the ensemble mean is 1.5. Therefore, the PlioMIP simulations give us confidence that ESS > CS, suggest ESS/CS is between 1.1 and 2, and imply a "best" estimate of 1.5.

A recent study (Palaeosens project members, 2012) has suggested a naming convention for distinguishing between estimates of climate and Earth system sensitivity, which highlights whether various processes are considered as forcings or feedbacks. In the notation of that study (which also recommends citing values in units of $\mathrm{K} / \mathrm{W} \mathrm{m}^{-2}$ ), we find here a palaeo sensitivity, $S^{\mathrm{p}}=S_{\left[\mathrm{CO}_{2}\right]}=1.35 \mathrm{~K} / \mathrm{W} \mathrm{m}^{-2}$ (assuming a radiative forcing from a doubling of $\mathrm{CO}_{2}$ of $3.7 \mathrm{~W} \mathrm{~m}^{-2}$ ).
The subscript $\left[\mathrm{CO}_{2}\right]$ of $S_{\left[\mathrm{CO}_{2}\right]}$ indicates that this estimate of sensitivity includes possible carbon cycle feedbacks as a forcing. Also in the notation of that paper, the fast-feedback climate sensitivity, $S^{\mathrm{a}}=0.91 \mathrm{~K} / \mathrm{W} \mathrm{m} \mathrm{m}^{-2}$.

A first caveat to these calculations of ESS versus CS is that specific models used within the PlioMIP Experiment 2 ensemble have non-negligible top of the atmosphere energy imbalances (TOA). The rate at which models progress towards energy balance varies from model to model, and the specified integration length, whilst being the best that could be pragmatically hoped for, was insufficient to bring all the models into approximate energy balance (Table 2 column f). However, the difference in TOA energy balance between each models pre-industrial control and Pliocene simulations is always $<1 \mathrm{~W} \mathrm{~m}^{-2}$. If the models that display a larger than $\sim 0.5 \mathrm{~W} \mathrm{~m}^{-2}$ imbalance are removed from the calculation of the ensemble mean ESS/CS, the ensemble mean ESS/CS still remains constant at 1.5. A further limitation is that there may be inconsistencies between the estimates of CS and ESS due to the fact that the CS estimates were not formally requested as part of PlioMIP. For example, integration length and initial condition may differ between the ESS and CS simulations.

A final caveat to our calculations of ESS is that changes in the Earth's orbit are not relevant to calculations of either CS or ESS. If reconstructed changes in global ice volume or vegetation distribution (i.e. the imposed longer term feedbacks) are even partly a function of orbital variability rather than $\mathrm{CO}_{2}$, the utility of the current experiments for understanding the sensitivity of climate in the context of future climate change is diminished. Initial transient mid-Pliocene climate simulations using Earth System Model of Intermediate Complexity are becoming available. Here $\mathrm{CO}_{2}$ forcing and orbital forcing have been imposed in isolation and in concert, and have suggested that a significant percentage of the additional feedback to global temperature derived from changes in vegetation cover and ice sheet extent may be attributable to orbital forcing (Ganopolski et al., 2011).

\section{Discussion and future outlook}

\subsection{PlioMIP Phase 2: recognising and reducing uncertainties (the PMIP Triangle)}

The data/model comparisons shown in section 4 do not consider temporal variability and uncertainty of the proxyestimated SST anomalies (see Dowsett et al., 2012). Therefore, whilst the identified patterns of data/model mismatch may appear convincing, they are likely to be an overestimate of the true level of discord between models and proxy data.

In any palaeo data/model comparison the cause of data/model mismatches will be complex and not attributable to a single factor in either the models or proxy data. In the context of PMIP three high-level causes of data/model discord require consideration. The first is limitations in 
model physics and structure, the second is uncertainties in the interpretation of proxy records, and the third is limitations of experimental design within the models. This triangle of uncertainty, which we term the PMIP Triangle, serves as a useful guide to establish a well-balanced assessment of the causes of disagreement between proxy data and model outputs.

In terms of the climate modelling for the Pliocene, PlioMIP is an effective means to quantify uncertainties in model predictions (the modelling vertex of the PMIP Triangle). So far PlioMIP has identified an envelope of climate possible from a collection of atmosphere-only and coupled atmosphere-ocean climate models set up to produce a single realisation of climate for the mPWP.

Given the known unknowns in providing models with "correct" boundary conditions for the mPWP, it would be advantageous for PlioMIP Phase 2 to focus on identifying a number of key sensitivity experiments to examine how poor constraints on atmospheric trace gasses, ice sheet configurations, palaeogeography and bathymetry could reduce the magnitude of data/model discord seen in the high latitudes of the Northern Hemisphere. Outlining a series of potential sensitivity tests, and allowing modelling groups to select which experiment or experiments they wish to run, would facilitate an efficient exploration of boundary condition uncertainty (experimental design vertex of the PMIP Triangle).

The final point of the PMIP Triangle to be considered is uncertainties in the interpretation of proxies which provide SAT and SST estimates. One of the most important of these uncertainties surrounds chronology and the time-averaged nature of the PRISM3D data set. Limitations in correlating one marine or land site to another over large geographical distances, favoured the establishment of a time slab in the Pliocene to which the ages of marine or terrestrial sites could be more confidently attributed (Dowsett and Poore, 1991). It also increased the potential amount of geological data that could be incorporated, and would therefore underpin any environmental reconstruction. The current PRISM time slab for marine reconstruction is $240000 \mathrm{yr}$ wide. The vegetation reconstruction is constructed by considering information from the entire Piacenzian Stage (1 million years wide).

Therefore, at each individual site the current PRISM palaeoenvironmental reconstruction represents an average of warm climate signals that occurred during the PRISM time slab (Dowsett et al., 2010; Salzmann et al., 2008). The PRISM reconstruction should not be considered as a reconstruction of environmental conditions that existed together at a discrete moment in time (i.e. a time slice). In terms of mPWP climate modelling studies using AGCMs this does not present a serious problem. The PRISM3D reconstruction allows AGCMs to examine what a global average warm climate during the mid-Pliocene might have looked like (e.g. Chandler et al., 1994; Sloan et al., 1996; Haywood et al., 2000).
However, outputs from the AOGCMs shown here have highlighted disconnections between the proxy data, which is representative of a time slab, and relatively short model integrations that predict an equilibrium climate state based on constant external forcing (see also Dowsett et al., 2012; Haywood et al., 2013). So whilst there have been a number of attempts to evaluate AOGCMs against the PRISM data set, including the data/model comparisons shown here, it is important to appreciate that neither the proxy data nor the climate models (due to imposed boundary conditions) are actually reproducing the same objective (i.e. a discrete moment in time during the $\mathrm{mPWP}$ ).

In reality climate model simulations run for 500 integrated years, using only a single realisation of orbit, $\mathrm{CO}_{2}$ and other forcings, cannot reproduce a reconstruction of average warm climate conditions over either 240000 or 1 million years, which reflect multiple changing and interacting forcing mechanisms (e.g. orbital forcing, trace gasses etc.). Whilst the PRISM palaeoenvironmental reconstruction provides outstanding insights into the Pliocene, the methods used in its construction are not ideal for the specific purpose of data/model comparison. We hypothesise that a component of the observed model-data inconsistency is related to the time slab nature of the proxy data within the PRISM3D data set. Progress in ameliorating potential discrepancies between models and data for the MPWP in the future relies upon the identification of a discrete time slice, or slices, for environmental reconstruction within the Pliocene epoch.

We accept that intrinsic complications of interpreting and understanding different proxy data sets will exist in both a time slice and time slab approach. Our suggestions do not invalidate essential work to interrogate the veracity of proxy reconstructions by all means at our disposal, including coordinated intercomparison of proxy data. However, a time slice approach removes some of the uncertainties in environmental forcing, providing an opportunity to identify the cause of patterns of data/model discord more easily. It also provides models with a physically sound target and it provides a means to reduce uncertainty in both environmental reconstruction and modelling simultaneously.

\subsection{PlioMIP: towards the identification and adoption of a Pliocene time slice(s)}

Any criteria established to aid in the identification of a Pliocene time slice(s) for palaeoenvironmental reconstruction will be subjective. In essence the criteria will be dependent upon specific scientific circumstances and the aim and objectives of the study. Given the potential utility of the Pliocene to understand the dynamics of warm climates, as well as elucidate Climate/Earth System Sensitivity, Haywood et al. (2013) proposed that a time slice displaying a near modern orbital configuration within a known warm peak in the benthic oxygen isotope record would represent the most logical choice for an initial time slice reconstruction. Such a 

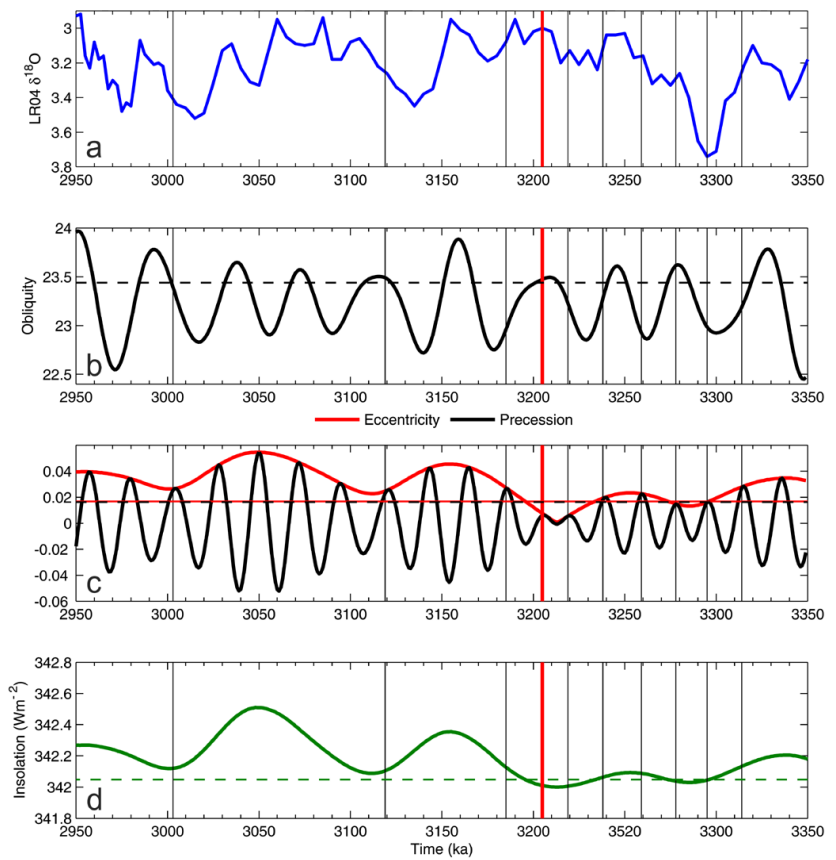

Fig. 7. Orbital variations between 2.950 and $3.350 \mathrm{Ma}$. (a) the Lisiecki and Raymo (2005) benthic oxygen isotope stack. (b) obliquity, with dashed horizontal showing the present-day value, (c) precession and eccentricity, with horizontal dashed black and solid red lines showing present-day values for eccentricity and precession, as derived from the astronomical solution of Laskar et al. (2004; La04). (d) the variation in global mean TOA insolation according to La04, with the dashed horizontal green line denoting the modern value of global mean insolation. The vertical black solid lines and the solid red line through each panel represent the best-fit solutions to the modern orbits as well as the selected initial time slice for investigation discussed in Sect. 6.2 (figure modified from Haywood et al., 2013).

strategy also has the advantage of simplifying the interpretation of geological proxies, because palaeo-seasonality has more chance of being the same or very similar to modern seasonality.

The Haywood et al. (2013) recommendation for an initial time slice at 3.205 Ma BP for reconstruction sits in the normal polarity of the Gauss Chron between the Kaena (above) and Mammoth (below) reversals (Fig. 7). The peak deviation in benthic $\delta^{18} \mathrm{O}$ is centred on Marine Isotope Stage KM5c (or KM5.3). The 0.21 to $0.23 \%$ o deviation in $\delta^{18} \mathrm{O}$ could reflect a 21 to $23 \mathrm{~m}$ sea level rise above modern (assuming $0.1 \%$ o equates to $\sim 10 \mathrm{~m}$ of sea level rise, Miller et al., 2012), providing that the signal is purely a function of ice volume rather than any change in deep ocean temperatures. Assuming the near-total loss of the West Antarctic and Greenland Ice Sheets (a reasonable initial premise given proxy data and model outputs; Naish et al., 2009; Pollard and DeConto, 2009; Dolan et al., 2011; Lunt et al., 2008), volume reduction from the East Antarctic Ice sheet is a moderate 6 or $7 \mathrm{~m}$ of ice volume equivalent. This general interpretation of sea level from the LR04 stack is supported by a recent synthesis of sea level records between 2.9 and 3.3 Ma BP by Miller et al. (2012). At $\sim 3.205 \mathrm{Ma}$ BP the Miller et al. (2012) synthesis indicates a maximum sea level rise of $25 \mathrm{~m} \pm 5 \mathrm{~m}$ (derived from $\mathrm{Mg} / \mathrm{Ca}$ ratios of deep marine ostracods; Dwyer and Chandler, 2009). A mean of multiple sea level records for approximately the same time indicates a peak sea level rise of $\sim 22 \mathrm{~m} \pm 10 \mathrm{~m}$.

During the time slice orbital forcing is close to the modern distribution both seasonally and regionally (Haywood et al., 2013). Additionally, it is preceded by a relatively stable interval (ca. $10 \mathrm{ka}$ ) where the insolation distribution is close to modern. During this period, analysis of the insolation patterns indicate that it is likely to have been dominated by progressively warmer Southern Hemisphere summers. This is consistent with the benthic $\delta^{18} \mathrm{O}$ variation seen in the LR04 stack, if ice sheet melt in Antarctica is a primary driver of the $\delta^{18} \mathrm{O}$ peak. Available proxy data for atmospheric $\mathrm{CO}_{2}$ (e.g. Bartoli et al., 2011) places an upper limit of $\sim 400 \mathrm{ppmv}$, with a cluster of four measurements within $100 \mathrm{ka}$ using three different proxy techniques (alkenones, boron isotopes and stomatal density) indicating a range of between 300 to 380 ppmv (Haywood et al., 2013).

\section{Conclusions}

We present, for the first time, a systematic model intercomparison and model-data comparison of the results from eleven climate models simulating the mid-Pliocene Warm period. This study includes outputs from atmosphere-only (Experiment 1; including outputs from seven models) as well as coupled atmosphere-ocean climate models (Experiment 2; including outputs from eight models). Model results show a range of global mean surface temperature anomalies, even though the models were specified with identical boundary conditions. In other words, models respond differently to the forcing derived from Pliocene boundary conditions. For Experiment 2, the range in global annual mean surface air temperature warming is $1.76^{\circ} \mathrm{C}$. For sea surface and surface air temperature, the models are least consistent with each other in the North Atlantic and in the high latitudes, respectively. For precipitation they are least consistent with each other in the tropics. Whilst all models predict an enhancement of the hydrological cycle, the magnitude of this enhancement is variable, and regional disparities in total precipitation are apparent. All models simulate a polar amplification of surface air temperature warming for the Pliocene, although the magnitude of this amplification is model dependant. Our ensembles support previous work suggesting that Earth System Sensitivity (ESS) is greater than Climate Sensitivity (CS), and suggest the ratio of ESS to CS is is between 1 and 2. 
Within the ensemble range, the models appear able to reproduce many of the sea surface and surface air temperature anomalies reconstructed from multiple proxies in the Southern Hemisphere, the tropics, and in the Northern Hemisphere (to $\sim 40^{\circ} \mathrm{N}$ ). At higher latitudes in the Northern Hemisphere point-to point data/model comparisons indicate that models potentially the magnitude of change on land and in the oceans. Comparison of regional averages highlight Russia and Siberia as particular areas of concern. Whilst these results provide justification for new sensitivity studies specifically targeted towards improving the match between data and models in the higher-latitudes of the Northern Hemisphere, they also highlight the need for reduced uncertainties in temperature estimates from geological temperature proxies. We highlight a strategy towards the adoption of more tightly constrained time slices (Haywood et al., 2013), rather than the current time slab approach, where proxy data may be derived from a window of time as wide as one million years, to help reduce uncertainties in proxy data and the experimental design used in future climate model simulations. Such a combined approach will allow for assessments of model performance for the Pliocene to be made with greater confidence in the future.

\section{Supplementary material related to this article is available online at: http://www.clim-past.net/9/191/2013/ cp-9-191-2013-supplement.zip.}

Acknowledgements. A.M.H., A.M.D. and S.J.P. acknowledge that the research leading to these results has received funding from the European Research Council under the European Union's Seventh Framework Programme (FP7/2007-2013)/ERC grant agreement no. 278636. A.M.D. acknowledges the UK Natural Environment Research Council for the provision of a Doctoral Training Grant. D.J.H. acknowledges the Leverhulme Trust for the award of an Early Career Fellowship and the National Centre for Atmospheric Research and the British Geological Survey for financial support. C.S. and G.L. received funding through POLMAR and PACES. Z.Z. would like to thank Mats Bentsen, Jerry Tjiputra, Ingo Bethke from Bjerknes Center for Climate Research for the contribution to the development of the NorESM-L. F.J.B. and D.J.L. acknowledge NERC grant NE/H006273/1. D.J.L. acknowledges Research Councils UK for the award of an RCUK fellowship and the Leverhulme Trust for the award of a Phillip Leverhulme Prize. B.L.O. and N.A.R. recognise that NCAR is sponsored by the US National Science Foundation (NSF) and computing resources were provided by the Climate Simulation Laboratory at NCAR's Computational and Information Systems Laboratory (CISL), sponsored by the NSF and other agencies. The source code of MRI model is provided by S. Yukimoto, O. Arakawa, and A. Kitoh in Meteorological Research Institute, Japan. Funding for L.S. and M.C. provided by NSF Grant ATM0323516 and NASA Grant NNX10AU63A. W.-L.C. and A.A.-O. would like to thank R. Ohgaito for help in setting up the MIROC4m experiments which were run on the Earth Simulator at JAMSTEC. H.J.D. thanks the
US Geological Survey Climate and Land Use Change Research and Development Program and the John Wesley Powell Center for Analysis and Synthesis. U.S. and A.M.H. acknowledge funding received from the Natural Environment Research Council (NERC Grant NE/I016287/1, and NE/G009112/1 along with D.J.L). The HadCM3 simulations were carried out using the computational facilities of the Advanced Computing Research Centre, University of Bristol - http://www.bris.ac.uk/acrc/.

Edited by: C. Brierley

\section{References}

Bartoli, G., Hönisch, B., and Zeebe, R. E.: Atmospheric $\mathrm{CO}_{2}$ decline during the Pliocene intensification of Northern Hemisphere glaciations, Paleoceanography, 26, PA4213, doi:10.1029/2010PA002055, 2011.

Bonan, G. B., Oleson, K. W., Vertenstein, M., Levis, S., Zeng, X., Dai, Y., Dickinson, R. E., and Yang, Z.-L.: The land surface climatology of the Community Land Model coupled to the NCAR Community Climate Model, J. Climate, 15, 3123-3149, 2002.

Braconnot, P., Otto-Bliesner, B., Harrison, S., Joussaume, S., Peterchmitt, J.-Y., Abe-Ouchi, A., Crucifix, M., Driesschaert, E., Fichefet, Th., Hewitt, C. D., Kageyama, M., Kitoh, A., Laîné, A., Loutre, M.-F., Marti, O., Merkel, U., Ramstein, G., Valdes, P., Weber, S. L., Yu, Y., and Zhao, Y.: Results of PMIP2 coupled simulations of the Mid-Holocene and Last Glacial Maximum Part 1: experiments and large-scale features, Clim. Past, 3, 261277, doi:10.5194/cp-3-261-2007, 2007.

Bragg, F. J., Lunt, D. J., and Haywood, A. M.: Mid-Pliocene climate modelled using the UK Hadley Centre Model: PlioMIP Experiments 1 and 2, Geosci. Model Dev., 5, 1109-1125, doi:10.5194/gmd-5-1109-2012, 2012.

Cattle, H. and Crossley, J.: Modelling arctic climate change, Philos. T. Roy. Soc. A, 352, 201-213, 1995.

Chan, W.-L., Abe-Ouchi, A., and Ohgaito, R.: Simulating the midPliocene climate with the MIROC general circulation model: experimental design and initial results, Geosci. Model Dev., 4, 1035-1049, doi:10.5194/gmd-4-1035-2011, 2011.

Chandler, M., Rind, D., and Thompson, R.: Joint investigations of the middle Pliocene climate II: GISS GCM Northern Hemisphere results, Global Planet. Change, 9, 197-219, 1994.

Chandler, M. A., Sohl, L. E., Jonas, J. A., and Dowsett, H. J.: Simulations of the Mid-Pliocene Warm Period using the NASA/GISS ModelE2-R Earth System Model, Geosci. Model Dev. Discuss., 5, 2811-2842, doi:10.5194/gmdd-5-2811-2012, 2012.

Charney, J. G.: Carbon Dioxide and Climate: A Scientific Assessment, National Academy of Science, Washington, DC, 22 pp., 1979.

Collins, W. D., Rasch, P. J., Boville, B. A., Hack, J. J., McCaa, J. R., Williamson, D. L., Kiehl, J. T., and Briegleb, B.: Description of the NCAR Community Atmosphere Model (CAM3.0), NCAR Tech. Note NCAR/TN-464+STR, National Center for Atmospheric Research, Boulder, Colorado, 226 pp., 2004.

Contoux, C., Ramstein, G., and Jost, A.: Modelling the midPliocene Warm Period climate with the IPSL coupled model and its atmospheric component LMDZ5A, Geosci. Model Dev., 5, 903-917, doi:10.5194/gmd-5-903-2012, 2012. 
Cox, P. M., Betts, R. A., Bunton, C. B., Essery, R. L. H., Rowntree, P. R., and Smith, J.: The impact of new land surface physics on the GCM simulation of climate and climate sensitivity, Clim. Dynam., 15, 183-203, 1999.

Cronin, T. M., Whatley, R. C., Wood, A., Tsukagoshi, A., Ikeya, N., Brouwers, E. M., and Briggs, W. M.: Microfaunal evidence for elevated mid-Pliocene temperatures in the Arctic Ocean, Paleoceanography, 8, 161-173, 1993.

Danabasoglu, G., Bates, S., Briegleb, B. P., Jayne, S. R., Jochum, M., Large, W. G., Peacock, S., and Yeager, S. G.: CCSM4 Ocean Component, J. Climate, 25, 1361-1389, 2012.

Dekens, P. S., Ravelo, A. C., and McCarthy, M.D.: Warm Upwelling Regions in the Pliocene Warm Period, Paleoceanography, 22, PA3211, doi:10.1029/2006PA001394, 2007.

Dolan, A. M., Haywood, A. M., Hill, D. J., Dowsett, H. J., Hunter, S. J., Lunt, D. J., and Pickering, S.: Sensitivity of Pliocene ice sheets to orbital forcing, Palaeogeogr., Palaeocl., 309, 98-110, 2011

Dowsett, H. J. and Cronin, T. M.: High eustatic sea level during the Middle Pliocene: Evidence from the southeastern U.S. Atlantic Coastal Plain, Geology, 18, 435-438, 1990.

Dowsett, H. J. and Poore, R. Z.: Pliocene sea surface temperatures of the North Atlantic Ocean at 3.0 Ma, Quaternary Sci. Rev., 10, 189-204, 1991.

Dowsett, H. J., Robinson, M. M., and Foley, K. M.: Pliocene threedimensional global ocean temperature reconstruction, Clim. Past, 5, 769-783, doi:10.5194/cp-5-769-2009, 2009.

Dowsett, H. J., Robinson, M., Haywood, A. M., Salzmann, U., Hill, D. J., Sohl, L., Chandler, M. A., Williams, M., Foley, K., and Stoll, D.: The PRISM3D Paleoenvironmental Reconstruction, Stratigraphy, 7, 123-139, 2010.

Dowsett, H. J., Haywood, A. M., Valdes, P. J., Robinson, M. M., Lunt, D. J., Hill, D. J., Stoll, D. K., and Foley, K. M.: Sea surface temperatures of the mid-Piacenzian Warm Period: A comparison of PRISM3 and HadCM3, Palaeogeogr. Palaeocl., 309, 83-91, 2011

Dowsett, H. J., Robinson, M. M., Haywood, A. M., Hill, D. J., Dolan, A. M., Stoll, D. K., Chan, W. L., Abe-Ouchi, A., Chandler, M. A., Rosenbloom, N. A., Otto-Bleisner, B. L., Bragg, F. J., Lunt, D. J., Foley, K. M., and Riesselman, C. R.: Assessing confidence in Pliocene sea surface temperatures to evaluate predictive models, Nature Climate Change, 2, 365-371, 2012.

Dufresne, J. L., Foujols, M. A., Denvil, S., Caubel, A., Marti, O., Aumont, O., Balkanski, Y., Bekki, S., Bellenger, H., Benshila, R., Bony, S., Bopp, L., Braconnot, P., Brockmann, P., Cadule, P., Cheruy, F., Codron, F., Cozic, A., Cugnet, D., de Noblet, N., Duval, J. P., Ethe, C., Fairhead, L., Fichefet, T., Flavoni, S., Friedlingstein, P., Grandpeix, J. Y., Guez, L., Guilyardi, E., Hauglustaine, D., Hourdin, F., Idelkadi, A., Ghattas, J., Joussaume, S., Kageyama, M., Krinner, G., Labetoulle, S., Lahellec, A., Lefebvre, M. P., Lefevre, F., Levy, C., Li, Z. X., Lloyd, J., Lott, F., Madecm G., Mancip, M., Marchand, M., Masson, S., Meurdesoif, Y., Mignot, J., Musat, I., Parouty, S., Polcher, J., Rio, C., Schulz, M., Swingedouw, D., Szopa, S., Talandier, C., Terray, P., and Viovy, N.: Climate change projections using the IPSL-CM5 Earth System Model: from CMIP3 to CMIP5, Clim. Dynam., submitted, 2013.

Dwyer, G. S. and Chandler, M. A.: Mid-Pliocene sea level and continental ice volume based on coupled benthic $\mathrm{Mg} / \mathrm{Ca}$ palaeotem- peratures and oxygen isotopes, Philos. T. Roy. Soc. A, 367, $157-$ $168,2009$.

Fichefet, T. and Morales-Maqueda, M. A.: Sensitivity of a global sea ice model to the treatment of ice thermodynamics and dynamics, J. Geophys. Res., 102, 12609-12646, doi:10.1029/97JC00480, 1997.

Fichefet, T. and Morales-Maqueda, M. A.: Modelling the influence of snow accumulation and snow-ice formation on the seasonal cycle of the Antarctic sea-ice cover, Clim. Dynam., 15, 251-268, doi:10.1007/s003820050280, 1999.

Ganopolski, A., Calov, R., Robinson, A., and Willeit, M.: Analysis of the role of climate forcings and feedbacks for the MidPliocene climate using a set of transient simulations from an Earth System Model, Abstract PP13B-1824 presented at 2011 Fall Meeting, AGU, San Francisco, Calif., 5-9 December, 2011.

Gent, P. R., Danabasoglu, G., Donner, L. J., Holland, M. M., Hunke, E. C., Jayne, S. R., Lawrence, D. M., Neale, R. B., Rasch, P. J., Vertenstein, M., Worley, P. H., Yang, Z. L., and Zhang, M.: The Community Climate System Model version 4, J. Climate, 24, 4973-4991, 2012.

Gordon, C., Cooper, C., Senior, C. A., Banks, H., Gregory, J. M., Johns, T. C., Mitchell, J. F. B., and Wood, R. A.: The simulation of SST, sea ice extents and ocean heat transports in a version of the Hadley Centre coupled model without flux adjustments, Clim. Dynam., 16, 147-168, 2000.

Gradstein, F. M., Ogg, J. G., and Smith, A. G.: A geologic time scale 2004: Cambridge University Press, 589 pp., 2004.

Hagemann, S. and Düemenil, L.: Documentation for the Hydrological Discharge Model, DKRZ Technical Report No. 17, Deutsches Klimarechenzentrum, Hamburg, 1998.

Hagemann, S. and Gates, L. D.: Improving a subgrid runoff parameterization scheme for climate models by the use of high resolution data derived from satellite observations, Clim. Dynam., 21, 349-359, doi:10.1007/s00382-003-0349-x, 2003.

Hansen, J., Sato, M., Ruedy, R., Kharecha, P., Lacis, A., Miller, R. L., Nazarenko, L., Lo, K., Schmidt, G. A., Russell, G., Aleinov, I., Bauer, S., Baum, E., Cairns, B., Canuto, V., Chandler, M., Cheng, Y., Cohen, A., Del Genio, A., Faluvegi, G., Fleming, E., Friend, A., Hall, T., Jackman, C., Jonas, J., Kelley, M., Kiang, N. Y., Koch, D., Labow, G., Lerner, J., Menon, S., Novakov, T., Oinas, V., Perlwitz, J. P., Perlwitz, J., Rind, D., Romanou, A., Schmunk, R., Shindell, D., Stone, P., Sun, S., Streets, D., Tausnev, N., Thresher, D., Unger, N., Yao, M., and Zhang, S.: Climate simulations for 1880-2003 with GISS modelE, Clim. Dynam., 29, 661-696, doi:10.1007/s00382-007-0255-8, 2007.

Hansen, J., Sato, M., Kharecha, P., Beerling, D., Berner, R., Masson-Delmotte, V., Pagani, M., Raymo, M., Royer, D. L., and Zachos, J. C.: Target atmospheric $\mathrm{CO}_{2}$ : Where should humanity aim?, Open Atmos. Sci. J., 2, 217-231, 2008.

Haywood, A. M. and Valdes, P. J.: Modelling Middle Pliocene warmth: contribution of atmosphere, oceans and cryosphere, Earth Planet. Sc. Lett., 218, 363-377, 2004.

Haywood, A. M., Valdes, P. J., and Sellwood, B. W.: Global scale palaeoclimate reconstruction of the middle Pliocene climate using the UKMO GCM: initial results, Global Planet. Change, 25, 239-256, 2000.

Haywood, A. M., Valdes, P. J., and Peck, V. L.: A permanent El Nino-like state during the Pliocene?, Paleoceanography, 22, PA1213, doi:10.1029/2006PA001323, 2007. 
Haywood, A. M., Chandler, M. A., Valdes, P. J., Salzmann, U., Lunt, D. J., and Dowsett, H. J.: Comparison of mid-Pliocene climate predictions produced by the HadAM3 and GCMAM3 General Circulation Models, Global Planet. Change, 66, 208-224, doi:10.1016/j.gloplacha.2008.12.014, 2009.

Haywood, A. M., Dowsett, H. J., Otto-Bliesner, B., Chandler, M. A., Dolan, A. M., Hill, D. J., Lunt, D. J., Robinson, M. M., Rosenbloom, N., Salzmann, U., and Sohl, L. E.: Pliocene Model Intercomparison Project (PlioMIP): experimental design and boundary conditions (Experiment 1), Geosci. Model Dev., 3, 227-242, doi:10.5194/gmd-3-227-2010, 2010.

Haywood, A. M., Dowsett, H. J., Robinson, M. M., Stoll, D. K., Dolan, A. M., Lunt, D. J., Otto-Bliesner, B., and Chandler, M. A.: Pliocene Model Intercomparison Project (PlioMIP): experimental design and boundary conditions (Experiment 2), Geosci. Model Dev., 4, 571-577, doi:10.5194/gmd-4-571-2011, 2011.

Haywood, A. M., Dolan, A. M., Pickering, S. J., Dowsett, H. J., McClymont, E. L., Prescott, C. L., Salzmann, U., Hill, D. J., Hunter, S. J., Lunt, D. J., and Valdes, P. J.: On the identification of a Pliocene time slice(s) for data-model comparison, Philos. T. R. Soc. Lond., in press, 2013.

Hibler, W. D.: A Dynamic Thermodynamic Sea Ice Model, J. Phys. Oceanogr., 9, 815-846, 1979.

Hill, D. J., Haywood, A. M., Hindmarsh, R. C. M., and Valdes, P. J.: Characterizing ice sheets during the Pliocene: evidence from data and models, in: Deep-Time Perspectives on Climate Change: Marrying the signal from Computer Models and Biological Proxies, edited by: Williams, M., Haywood, A. M., Gregory, F. J., and Schmidt, D. N., The Micropalaeontological Society, Special Publications, The Geological Society, London, 517-538, 2007.

Hill, D. J., Dolan, A. M., Haywood, A. M., Hunter, S. J., and Stoll, D. K.: Sensitivity of the Greenland Ice Sheet to Pliocene sea surface temperatures, Stratigraphy, 7, 111-122, 2010.

Hoar, M. R., Palutikof, J. P., and Thorne, M. C.: Model intercomparison for the present day, the mid-Holocene, and the Last Glacial Maximum over Western Europe, J. Geophys. Res., 109, D08104, doi:10.1029/2003JD004161, 2004.

Holland, M. M., Bailey, D. A., Briegleb, B. P., Light, B., and Hunke, E. C.: Improved sea ice shortwave radiation physics in CCSM4: The impact of melt ponds and black carbon, J. Climate, 25, 14131430, doi:10.1175/JCLI-D-11-00078.1, 2012.

Hourdin, F., Musat, I., Bony, S., Braconnot, P., Codron, F., Dufresne, J.-F., Fairhead, L., Filiberti, M.-A., Friedlingstein, P., Grandpeix, J.-Y., Levan, P., Li, Z.-X., and Lott, F.: The LMDZ4 general circulation model: climate performance and sensitivity to parametrized physics with emphasis on tropical convection, Clim. Dynam., 27, 787-813, 2006.

Hourdin F., Foujols, M.-A., Codron, F., Guemas, V., Dufresne, J.L., Bony, S., Denvil, S., Guez, L., Lott, F., Ghattas, J., Braconnot, P., Marti, O., Meurdesoif, Y., and Bopp, L.: Climate and sensitivity of the IPSL-CM5A coupled model: impact of the LMDZ atmospheric grid configuration, Clim. Dynam., online first: doi:10.1007/s00382-012-1411-3, 2012.

Hunke, E. C. and Lipscomb, W. H.: CICE: the Los Alamos Sea Ice Model Documentation and Software User's Manual Version 4.1, 2010.

Joussaume, S. and Taylor, K. E.: Status of the Paleoclimate Modeling Intercomparison Project (PMIP), Proceedings of the First
International AMIP Scientific Conference, WCRP Report, 425430, 1995.

Jungclaus, J. H., Keenlyside, N., Botzet, M., Haak, H., Luo, J.J., Latif, M., Marotzke, J., Mikolajewicz, U., and Roeckner, E.: Ocean Circulation and Tropical Variability in the Coupled Model ECHAM5/MPI-OM, J. Climate, 19, 3952-3972, doi:10.1175/JCLI3827.1, 2006.

K-1 Model Developers: K1 Coupled Model (MIROC) Description: K1 Technical Report 1, edited by: Hasumi, H. and Emori, S., 34 pp., Center for Climate System Research, University of Tokyo, 2004.

Kamae, Y. and Ueda, H.: Mid-Pliocene global climate simulation with MRI-CGCM2.3: set-up and initial results of PlioMIP Experiments 1 and 2, Geosci. Model Dev., 5, 793-808, doi:10.5194/gmd-5-793-2012, 2012.

Kamae, Y., Ueda, H., and Kitoh, A.: Hadley and Walker circulations in the mid-Pliocene warm period simulated by an atmospheric general circulation model, J. Meteorol. Soc. Jpn., 89, 475-493, 2011.

Kelly, K. A., Small, R. J., Samelson, R. M., Qiu, B., Joyce, T. M., Kwon, Y.-O., and Cronin, M. F.: Western boundary currents and frontal air-sea interaction: Gulf Stream and Kuroshio Extension, J. Climate, 23, 5644-5667, doi:10.1175/2010JCLI3346.1, 2010.

Kiang, N. Y., Koster, R. D., Moorcroft, P. R., Ni-Meister, W., and Rind, D.: A dynamic global terrestrial ecosystem model for coupling with GCMs, American Geophysical Union Fall Meeting, San Francisco, CA, 10-15 December 2006.

Koenig, S. J., DeConto, R. M., and Pollard, D.: Pliocene Model Intercomparison Project Experiment 1: implementation strategy and mid-Pliocene global climatology using GENESIS v3.0 GCM, Geosci. Model Dev., 5, 73-85, doi:10.5194/gmd-5-732012, 2012.

Krinner, G., Viovy, N., de Noblet-Ducoudre, N., Ogee, J., Polcher, J., Friedlingstein, F., Ciais, P., Sitch, S., and Prentice, I. C.: A dynamic global vegetation model for studies of the coupled atmosphere-biosphere system, Global Biogeochem. Cy., 19, GB1015, doi:10.1029/2003GB002199, 2005.

Laskar, J., Robutel, P., Joutel, F., Gastineau, M., Correia, A. C. M., and Levrard, B.: A long term numerical solution for the insolation quantities of the Earth, Astron. Astrophys., 428, 261-285, 2004.

Lawrence, D. M., Oleson, K. W., Flanner, M. G., Fletcher, C. G., Lawrence, P. J., Levis, S., Swenson, S. C., and Bonan, G. B.: The CCSM4 Land Simulation, 1850-2005: Assessment of Surface Climate and New Capabilities, J. Climate, 25, 2240-2260, 2012.

Le Treut, H., Somerville, R., Cubasch, U., Ding, Y., Mauritzen, C., Mokssit, A., Peterson, T., and Prather, M.: Historical Overview of Climate Change, in: Climate Change 2007: The Physical Science Basis. Contribution of Working Group I to the Fourth Assessment Report of the Intergovernmental Panel on Climate Change, edited by: Solomon, S., Qin, D., Manning, M., Chen, Z., Marquis, M., Averyt, K. B., Tignor M., and Miller, H. L., Cambridge University Press, Cambridge, United Kingdom and New York, NY, USA, 2007.

Lisiecki, L. E. and Raymo, M. E.: A Pliocene-Pleistocene stack of 57 globally distributed benthic $\delta^{18} \mathrm{O}$ records, Paleoceanography, 20, PA1003, doi:10.1029/2004PA001071, 2005. 
Liu, J., Schmidt, G. A., Martinson, D., Rind, D. H., Russell, G. L., and Yuan, X.: Sensitivity of sea ice to physical parameterizations in the GISS global climate model, J. Geophys. Res., 108, 3053, doi:10.1029/2001JC001167, 2003.

Lunt, D. J., Foster, G. L., Haywood, A. M., and Stone, E. J.: Late Pliocene Greenland glaciation controlled by a decline in atmospheric $\mathrm{CO}_{2}$ levels, Nature, 454, 1102-1106, 2008.

Lunt, D. J., Haywood, A. M., Schmidt, G. A., Salzmann, U., Valdes, P. J., and Dowsett, H. J.: Earth system sensitivity inferred from Pliocene modelling and data, Nat. Geosci., 3, 60-64, 2010.

Madec, G., Delecluse, P., Imbard, M., and Levy C.: OPA version 8.1 Ocean general circulation model reference manual, 3. LODYC, Technical Report, 91 pp., available at: http://www.nemo-ocean. eu/About-NEMO/Reference-manuals, 1997.

Marsland, S. J., Haak, H., Jungclaus, J. H., Latif, M., and Roeske, F.: The Max-Planck-Institute global ocean/sea ice model with orthogonal curvilinear coordinates, Ocean Model., 5, 91-127, doi:10.1016/S1463-5003(02)00015-X, 2003.

Marti, O., Braconnot, P., Dufresne, J.-L., Bellier, J., Benshila, R., Bony, S., Brockmann, P., Cadule, P., Caubel, A., Codron, F., de Noblet, N., Denvil, S., Fairhead, L., Fichefet, T., Foujols, M.A., Friedlingstein, P., Goosse, H., Grandpeix, J.-Y., Guilyardi, E., Hourdin, F., Krinner, G., Lévy, C., Madec, G., Mignot, J., Musat, I., Swingedouw, D., and Talandier, C.: Key features of the IPSL ocean atmosphere model and its sensitivity to atmospheric resolution, Clim. Dynam., 34, 1-26, doi:10.1007/s00382-009-06406, 2010.

Meinshausen, M., Meinshausen, N., Hare, W., Raper, S. C. B., Frieler, K., Knutti, R., Frame, D. J., and Allen, M. R.: Greenhouse-gas emission targets for limiting global warming to $2{ }^{\circ} \mathrm{C}$, Nature, 458, 1158-1162, 2009.

Mellor, G. L. and Kantha, L.: An ice-ocean coupled model, J. Geophys. Res., 94, 10937-10954, 1989.

Miller, K. G., Wright, J. D., Browning, J. V., Kulpecz, A., Kominz, M., Naish, T. R., Cramer, B. S., Rosenthal, Y., Peltier, R., and Sosdian, S.: High tide of the warm Pliocene: Implications of global sea level for Antarctic deglaciation, Geology, 40, 407410, doi:10.1130/G32869.1, 2012.

Moran, K., Backman, J., Brinkhuis, H., Clemens, S. C., Cronin, T., Dickens, G. R., Eynaud, F. R., Gattacceca, J., Jakobsson, J., Jordan, R. W. Kaminski, M., King, J., Koc, N., Krylov, A., Martinez, N., Matthiessen, J., McInroy, D., Moore, T. C., Onodera, J., O'Regan, M., Palike, H., Rea, B., Rio, D., Sakamoto, T., Smith, D. C., Stein, R., St. John, K., Suto, I., Suzuki, N., Takahashi, K., Watanabe, M., Yamamoto, M., Farrell, J., Frank, M., Kubik, P., Jokat, W., and Kristoffersen, Y.: The Cenozoic palaeoenvironment of the Arctic Ocean, Nature, 441, 601-605, 2006.

Naish, T., Powell, R., Levy, R., Wilson, G., Scherer, R., Talarico, F., Krissek, L., Niessen, F., Pompilio, M., Wilson, T., Carter, L., DeConto, R., Huybers, P., McKay, R., Pollard, D., Ross, J., Winter, D., Barrett, P., Browne, G., Cody, R., Cowan, E., Crampton, J., Dunbar, G., Dunbar, N., Florindo, F., Gebhardt, C., Graham, I., Hannah, M., Hansaraj, D., Harwood, D., Helling, D., Henrys, S., Hinnov, L., Kuhn, G., Kyle, P., Läufer, A., Maffioli, P., Magens, D., Mandernack, K., McIntosh, W., Millan, C., Morin, R., Ohneiser, C., Paulsen, T., Persico, D., Raine, I., Reed, J., Riesselman, C., Sagnotti, L., Schmitt, D., Sjunneskog, C., Strong, P., Taviani, M., Vogel, S., Wilch, T., and Williams, T.: Obliquity-paced Pliocene West Antarctic ice sheet oscillations, Nature, 458, 322-
328, 2009.

Neale, R. B., Richter, J., Park, S., Lauritzen, P. H., Vavrus, S. J., Rasch, P. J., and Zhang, M.: The mean climate of the Community Atmosphere Model (CAM4) in forced SST and fully coupled experiments, J. Climate, submitted, 2013.

Oki, T. and Sud, Y. C.: Design of Total Runoff Integrating Pathways (TRIP), Global River Channel Network, Earth Interact., 2, 1-37, 1998.

Pagani, M., Liu, Z., LaRiviere, J., and Ravelo, A. C.: High Earth-system climate sensitivity determined from Pliocene carbon dioxide concentrations, Nat. Geosci., 3, 27-30, doi:10.1038/ngeo724, 2010.

Palaeosens project members: Making sense of palaeoclimate sensitivity, Nature, 491, 683-691, 2012.

Pollard, D. and DeConto, R. M.: Modelling West Antarctic ice sheet growth and collapse through the past five million years, Nature, 458, 329-332, 2009.

Polyak, L., Alley, R. B., Andrews, J. T., Brigham-Grette, J., Cronin, T. M., Darby, D. A., Dyke, A. S., Fitzpatrick, J. J., Funder, S., Holland, M., Jennings, A. E., Miller, G. H., O’Regan, M., Savelle, J., Serreze, M., St. John, K., White, J. W. C., and Wolff, E.: History of sea-ice in the Arctic, Quaternary Sci. Rev., 29, 1757-1778, 2010.

Pope, J. O., Collins, M., Haywood, A. M., Dowsett, H. J., Hunter, S. J., Lunt, D. J., Pickering, S. J., and Pound, M. J.: Quantifying Uncertainty in Model Predictions for the Pliocene (PlioQUMP): Initial results, Palaeogeogr. Palaeocl., 309, 128-140, doi:10.1016/j.palaeo.2011.05.004, 2011

Pope, V. D., Gallani, M. L., Rowntree, P. R., and Stratton, R. A.: The impact of new physical parametrizations in the Hadley Centre climate model: HadAM3, Clim. Dynam., 16, 123-146, 2000.

Prentice, I. C. and Webb III, T.: BIOME 6000: reconstructing global mid-Holocene vegetation patterns from palaeoecological records, J. Biogeogr., 25, 997-1005, 1998.

Raddatz, T. J., Reick, C. H., Knorr, W., Kattge, J., Roeckner, E., Schnur, R., Schnitzler, K.-G., Wetzel, P., and Jungclaus, J.: Will the tropical land biosphere dominate the climate-carbon cycle feedback during the twentyfirst century?, Clim. Dynam., 29, 565-574, doi:10.1007/s00382-007-0247-8, 2007.

Robinson, M. M., Valdes, P. J., Haywood, A. M., Dowsett, H. J., Hill, D. J., and Jones, S. M.: Bathymetric controls on Pliocene North Atlantic and Arctic sea surface temperature and deepwater production, Palaeogeogr. Palaeocl., 309, 92-97, doi:10.1016/j.palaeo.2011.01.004, 2011.

Rosenbloom, N. A., Otto-Bliesner, B. L., Brady, E. C., and Lawrence, P. J.: Simulating the mid-Pliocene Warm Period with the CCSM4 model, Geosci. Model Dev. Discuss., 5, 4269-4303, doi:10.5194/gmdd-5-4269-2012, 2012.

Roeckner, E., Baeuml, G., Bonaventura, L., Brokopf, R., Esch, M., Giorgetta, M., Hagemann, S., Kirchner, I., Kornblueh, L., Manzini, E., Rhodin, A., Schlese, U., Schulzweida, U., and Tompkins, A.: The atmospheric general circulation model ECHAM5, PART I: Model description, Report 349, Max-PlanckInstitut fuer Meteorologie, Hamburg, 2003.

Salzmann, U., Haywood, A. M., Lunt, D. J., Valdes, P. J., and Hill, D. J.: A new global biome reconstruction and data-model comparison for the Middle Pliocene, Global Ecol. Biogeogr., 17, 432-447, 2008. 
Salzmann, U., Dolan, A. M., Haywood, A. M., Abe-Ouchi, A., Bragg, F., Chan, W. L., Chandler, M. A., Lunt, D. J., OttoBliesner, B., Pound, M. J., and Rosenbloom, N.: How well do models reproduce warm terrestrial climates of the past? Nature Climate Change, submitted, 2013.

Sato, N., Sellers, P. J., Randall, D. A., Schneider, E. K., Shukla, J., Kinter, J. L., Hou, Y.-Y., and Albertazzi, E.: Effects of implementing the simple biosphere model in a general circulation model, J. Atmos. Sci., 46, 2757-2782, 1989.

Schmidt, G. A., Kelley, Á. M., Nazarenko, L., Ruedy, R., Russell, G. L., Aleinov, I., Bauer, M., Bauer, S., Bhat, M. K., Bleck, R., Canuto, V., Chen, Y., Cheng, Y., Clune, T. L., DelGenio, A., de Fainchtein, R., Faluvegi, G., Hansen, J. E., Healy, R. J., Kiang, N. Y., Koch, D., Lacis, A. A., LeGrande, A. N., Lerner, J., Lo, K. K., Marshall, J., Menon, S., Miller, R. L., Oinas, V., Oloso, A. O., Perlwitz, J., Puma, M. J., Putman, W. M., Rind, D., Romanou, A., Sato, M., Shindell, D. T., Sun, S., Syed, R. A., Tausnev, N., Tsigaridis, K., Unger, N., Voulgarakis, A., Yao, M.-S., Zhang, J.: Configuration and assessment of the GISS ModelE2 contributions to the CMIP5 archive, in preparation, 2012.

Seki, O., Foster, G. L., Schmidt, D. N., Mackensen, A., Kawamura, K., and Pancost, R. D.: Alkenone and boron based Pliocene $p \mathrm{CO}_{2}$ records, Earth Planetary Sc. Lett., 292, 201-211, doi:10.1016/j.epsl.2010.01.037, 2010.

Sellers, P. J., Mintz, Y., Sud, Y. C., and Dalcher, A.: A simple biosphere model $(\mathrm{SiB})$ for use within general circulation models, J. Atmos. Sci., 43, 505-531, 1986.

Sloan, L. C., Crowley, T. J., and Pollard, D.: Modeling of middle Pliocene climate with the NCAR GENESIS general circulation model, Mar. Micropaleontol., 27, 51-61, 1996.

Smith, R., Jones, P., Briegleb, B., Bryan, F., Donabasoglu, G., Dennis, J., Dukowicz, J., Eden, C., Fox-Kemper, B., Gent, P., Hecht, M., Jayne, S., Jochum, M., Large, W., Lindsay, K., Maltrud, M., Norton, N., Peacock, S., Vertenstein, M., and Yeager, S.: The Parallel Ocean Program (POP) reference manual: Ocean component of the Community Climate System Model (CCSM), Los Alamos National Laboratory Tech. Report, LAUR-10-01853, 140 pp., 2010 .
Sohl, L. E., Chandler, M. A., Schmunk, R. B., Mankoff, K., Jonas, J. A., Foley, K. M., and Dowsett, H. J.: PRISM3/GISS topographic reconstruction, US Geol. Surv. Data Series 419, 2009.

Stepanek, C. and Lohmann, G.: Modelling mid-Pliocene climate with COSMOS, Geosci. Model Dev., 5, 1221-1243, doi:10.5194/gmd-5-1221-2012, 2012.

Wan, S., Tian, J., Steinke, S., Li, A., and Li, T.: Evolution and variability of the East Asian summer monsoon during the Pliocene: Evidence from clay mineral records of the South China Sea, Palaeogeogr. Palaeocl., 293, 237-247, 2010.

Yan, Q., Zhang, Z. S., Wang, H. J., Gao, Y. Q., and Zheng, W. P.: Set-up and preliminary results of mid-Pliocene climate simulations with CAM3.1, Geosci. Model Dev., 5, 289-297, doi:10.5194/gmd-5-289-2012, 2012.

Yukimoto, S., Noda, A., Kitoh, A., Hosaka, M., Yoshimura, H., Uchiyama, T., Shibata, K., Arakawa, O., and Kusunoki, S.: Present-day and climate sensitivity in the meteorological research institute coupled GCM version 2.3 (MRI-CGCM2.3), J. Meteorol. Soc. Jpn., 84, 333-363, 2006.

Zhang, Z. and Yan, Q.: Pre-industrial and mid-Pliocene simulations with NorESM-L: AGCM simulations, Geosci. Model Dev., 5, 1033-1043, doi:10.5194/gmd-5-1033-2012, 2012.

Zhang, Z. S., Nisancioglu, K., Bentsen, M., Tjiputra, J., Bethke, I., Yan, Q., Risebrobakken, B., Andersson, C., and Jansen, E.: Pre-industrial and mid-Pliocene simulations with NorESM-L, Geosci. Model Dev., 5, 523-533, doi:10.5194/gmd-5-523-2012, 2012.

Zheng, W., Braconnot, P., Guilyardi, E., Merkel, U., and Yu, Y.: ENSO at $6 \mathrm{ka}$ and $21 \mathrm{ka}$ from ocean-atmosphere coupled model simulations, Clim. Dynam., 30, 745-762, 2008. 